\title{
sensors
}

ISSN 1424-8220

(C) 2005 MDPI

http://www.mdpi.org/sensors

\section{Overview of Sensors and Needs for Environmental Monitoring}

\author{
Clifford K. Ho*, Alex Robinson, David R. Miller and Mary J. Davis
}

Sandia National Laboratories, P.O. Box 5800, Albuquerque, NM 87185, USA. Tel: (505) 844-2384, Fax: (505) 844-7354.

* Author to whom correspondence should be addressed. E-mail: ckho@sandia.gov

Received: 31 August 2004 / Accepted: 01 December 2004 / Published: 28 February 2005

\begin{abstract}
This paper surveys the needs associated with environmental monitoring and longterm environmental stewardship. Emerging sensor technologies are reviewed to identify compatible technologies for various environmental monitoring applications. The contaminants that are considered in this report are grouped into the following categories: (1) metals, (2) radioisotopes, (3) volatile organic compounds, and (4) biological contaminants. United States regulatory drivers are evaluated for different applications (e.g., drinking water, storm water, pretreatment, and air emissions), and sensor requirements are derived from these regulatory metrics. Sensor capabilities are then summarized according to contaminant type, and the applicability of the different sensors to various environmental monitoring applications is discussed.
\end{abstract}

Keywords: environmental monitoring, sensors, regulatory standards. 


\section{Introduction}

Environmental monitoring is required to protect the public and the environment from toxic contaminants and pathogens that can be released into a variety of media including air, soil, and water. Air pollutants include sulfur dioxide, carbon monoxide, nitrogen dioxide, and volatile organic compounds, which originate from sources such as vehicle emissions, power plants, refineries, and industrial and laboratory processes. Soil and water contaminants can be classified as microbiological (e.g., coliform), radioactive (e.g., tritium), inorganic (e.g., arsenic), synthetic organic (e.g., pesticides), and volatile organic compounds (e.g., benzene). Pesticide and herbicides are applied directly to plants and soils, and incidental releases of other contaminants can originate from spills, leaking pipes, underground storage tanks, waste dumps, and waste repositories. Some of these contaminants can persist for many years and migrate through large regions of soil until they reach water resources, where they may present an ecological or human-health threat.

The United States Environmental Protection Agency (U.S. EPA) has imposed strict regulations on the concentrations of many environmental contaminants in air and water. However, current monitoring methods are costly and time-intensive, and limitations in sampling and analytical techniques exist. For example, Looney and Falta [1] report that the Department of Energy (DOE) Savannah River Site requires manual collection of nearly 40,000 groundwater samples per year, which can cost between $\$ 100$ to $\$ 1,000$ per sample for off-site analysis. Wilson et al. [2] report that as much as $80 \%$ of the costs associated with site characterization and cleanup of a Superfund site can be attributed to laboratory analyses. In addition, the integrity of the off-site laboratory analyses can be compromised during sample collection, transport, storage, and analysis, which can span several days or more. Clearly, a need exists for accurate, inexpensive, long-term monitoring of environmental contaminants using sensors that can be operated on site or in situ. However, the ability to deploy and use emerging sensors for these applications is uncertain due to both cultural and technological barriers.

The purpose of this report is to assess the needs of long-term environmental monitoring applications in the U.S. and to summarize the capabilities of emerging sensor technologies (with an emphasis on Sandia-developed sensor technologies). A market survey is presented that elucidates the costs, drivers, and potential benefits of using in-situ sensors for long-term environmental monitoring. Regulatory metrics for different environmental monitoring applications are then presented to provide requirements for the sensor technologies. Emerging sensor technologies that are being developed at Sandia National Laboratories are then evaluated that can be used to monitor environmental contaminants, particularly for long-term environmental stewardship. We limit our focus to four categories of contaminants: (1) metals, (2) radioisotopes, (3) volatile organic compounds, and (4) biological contaminants. For each contaminant, we seek portable sensors that can provide rapid responses (relative to current methods and technologies), ease of operation (for field use), and sufficient detection limits.

\section{Market survey}

In 2001, U.S. companies generated $\$ 213$ billion in environmental industry revenue, with a growth of $2.1 \%$ and exports representing $11 \%$ of this figure [3]. Overall, the environmental industry is in a state of evolution. The U.S. environmental remediation/industrial services markets have topped out 
and are projected to decline. A decline in hazardous waste management funding continues with a trend that began in 1993. Returns on investment in hazardous waste remediation technologies have been low for some time and the DOE continues to be the largest funding source within the U.S. for the site remediation market.

A $15 \%$ growth in the overall environmental industry is forecasted as the combination of two major groups. The first group is comprised of energy and water that is projected to experience growth ranging from $19 \%$ to over $250 \%$ during the first decade of the $21^{\text {st }}$ century [3]. The second group consists of compliance, remediation and waste management that are projected to decline $13 \%$ to $49 \%$ during the same timeframe. The first group is driven by economics and basic human needs while the second group is driven by regulations and enforcement.

The two best performing environmental industry segments are also the best performers over the past decade: clean energy systems/power $(+16 \%)$ and process/pollution prevention technology $(+9 \%)$. Clean energy systems/power $(\$ 10.0 \mathrm{~b})$ accounted for $65 \%$ of the overall market growth in dollars. Process and pollution prevention technology have annual revenues of $\$ 1.3$ billion. Continued growth of clean energy/power and process/pollution prevention technologies are projected.

Instrument technology is a $\$ 3.8$ billion dollar industry and has experienced an annual growth rate of approximately $4 \%$. The U.S. water industry - made up of water utilities $(\$ 30.9 \mathrm{~b})$, wastewater treatment works $(\$ 28.8 \mathrm{~b})$, and water equipment/chemicals $(\$ 20.3 \mathrm{~b})$ accounts for $38 \%$ of the environmental industry revenues. Solid waste management $(\$ 40.8 \mathrm{~b}$ ), air pollution control equipment $(\$ 18.3 \mathrm{~b})$ and consulting/engineering $(\$ 18.0 \mathrm{~b})$ are also major contributors to the environmental industry revenue stream.

In the present DOE Environmental Management (EM) market, technology investments are not occurring on a scale that is likely to make major cost and schedule differences. EM is focusing its resources on actual clean-ups and site closures and not on technology innovations. Low interest in technologies increases the difficulty in finding willing investors. Investors are likely to be wary of any growth potential in a market that has an environmental connotation. However, technologies that have a specific need that saves money can be successful. Technological improvements in excavation, transportation, disposal, analytical services, robotics, sample preparation, field sampling, and monitoring are examples of areas where technological improvements could be successful [4].

Data Quality Objectives (DQOs) must be considered as part of technology development and a focus should be made on the most urgent problems, such as situations where contaminants are in contact with groundwater. Regulator involvement in new technology development and acceptance of technologies is also very important [4].

Science and technology needs include methods of detection, analysis, remote sensing, and data transmission. A technology-needs analysis determined that the most important needs for analytical capabilities were the use of fieldable instrumentation for organic compounds in water/soil/air and for Resource Conservation and Recovery Act (RCRA) metals in water/soil [4]. It was further noted that a leap in technology would occur when the performance of the field instruments more closely approaches that of laboratory-based instruments. A potential application in long-term monitoring and stewardship is in the area of performance monitoring of water to address current technical uncertainties [5]. Additionally, information is needed to determine if ambient conditions change significantly enough over the long term to diminish the effectiveness of the remedy. 
Based on information gathered in equipment user surveys, an analysis of the market for environmental field instrumentation determined that field instrumentation has been expanding due to cost savings from on-site analysis and improved regulatory and customer acceptance of on-site methods [6]. The environmental field instrument market is expected to enjoy an average growth of $7 \%$ annually for the foreseeable future. The market will expand with technology developments and increasing regulatory acceptance. However, given the current regulatory environment, field instruments may never completely replace laboratory analysis, and therefore never realize its maximum market potential.

Remediation opportunities will wane and be replaced with smaller, longer-term opportunities related to post-closure monitoring and long-term stewardship. This should open doors to new instruments and measurement technologies and remote information management systems. The market consists of many niche applications, which are met by a number of different technologies. The longterm nature of post-closure monitoring and surveillance will be required at a wide variety of nuclear sites, uranium mill tailing sites, low-level and mixed-waste burial grounds, and hazardous waste sites that may create new areas for application. This market overlaps with other markets, such as for chemical industry process monitoring. Technology developments that can crosscut multiple areas within the environmental industry have a greater potential for success within the industry.

Long-term stewardship is not unique to the DOE. The EPA is currently determining its stewardship responsibilities through its Federal Facilities Restoration and Reuse Office. Both EPA Region IV and $\mathrm{X}$ have released policy documents on the use of institutional controls at Federal facilities. However, the specific ways in which long-term institutional control issues are implemented vary considerably at state and local offices. The Department of Defense (DoD) conducts cleanup activities at more than 10,000 sites, nearly 2,000 military installations and more than 9,000 formerly used defense properties. The Department of Interior (DoI) is responsible for overseeing approximately 13,000 former mining sites, some of which have been abandoned by the original owners. The nation's commitment is also not limited to federal properties. For example, sanitary and hazardous landfills, industrial facilities, and former waste management operations likely require long-term monitoring that will be funded by state and local governments.

The DOE conducts its stewardship activities in compliance with applicable laws, regulations, and inter-agency agreements. In general the DOE is required to implement some land-use controls at waste disposal facilities in perpetuity. Groundwater-monitoring timeframes are expected to be 30 years or greater. Costs of post-cleanup stewardship activities are currently unknown. However, a DOE Office of Inspector General audit found that the "DOE groundwater monitoring activities were not being conducted economically as they could have been since some sites had not adopted innovative technologies and approaches to well installations, sampling operations, and laboratory analysis." The report concluded that in part this occurred because innovative groundwater monitoring techniques were either unavailable or had not been effectively disseminated, evaluated for applicability at other sites and implemented" [7]. In summary, the development of sensors for long-term groundwater monitoring may fill a niche that could have a wide-ranging application for long-term environmental monitoring. 


\section{Regulatory requirements, standards and policies}

\section{Drinking water}

National Primary Drinking Water Regulations apply to public water systems and are legally enforceable standards. These primary standards are intended to protect public health by limiting the levels of contaminants that can be found in drinking water. Although these standards are applicable to public water systems (i.e., at the tap), they are often applied by remediation regulators in the aquifer (i.e., at the monitoring wellhead). The following tables (Tab. 1 to Tab. 6) summarize the drinking water standards imposed by the U.S. Environmental Protection Agency (EPA). Additional information regarding potential health impacts and sources of contamination can also be found at their web site (http://www.epa.gov/safewater/mcl.html).

Table 1. EPA national primary drinking water standards for microorganisms.

\begin{tabular}{|l|c|c|}
\hline \multicolumn{1}{|c|}{ Contaminant } & $\begin{array}{c}\text { Maximum Contaminant } \\
\text { Level Goal (mg/L) }\end{array}$ & $\begin{array}{c}\text { Maximum Contaminant Level } \\
\text { (mg/L) }\end{array}$ \\
\hline Cryptosporidium & zero & See footnote* $^{*}$ \\
\hline Giardia lamblia & zero & See footnote $^{*}$ \\
\hline Heterotrophic plate count & n/a & See footnote $^{*}$ \\
\hline Legionella & zero & See footnote $^{*}$ \\
\hline Total Coliforms (including fecal coliform and E. Coli) & zero & f.0 $^{* *}$ \\
\hline Turbidity & n/a & See footnote $^{*}$ \\
\hline Viruses (enteric) & zero & See footnote $^{*}$ \\
\hline
\end{tabular}

*EPA's surface water treatment rules require systems using surface water or ground water under the direct influence of surface water to (1) disinfect their water, and (2) filter their water or meet criteria for avoiding filtration so that the following contaminants are controlled at the following levels:

- Cryptosporidium (as of1/1/02 for systems serving $>10,000$ and $1 / 14 / 05$ for systems serving $<10,000$ ) $99 \%$ removal.

- Giardia lamblia: 99.9\% removal/inactivation.

- Viruses: $99.99 \%$ removal/inactivation.

- Legionella: No limit, but EPA believes that if Giardia and viruses are removed/inactivated, Legionella will also be controlled.

- Turbidity: At no time can turbidity (cloudiness of water) go above 5 nephelolometric turbidity units (NTU); systems that filter must ensure that the turbidity go no higher than $1 \mathrm{NTU}(0.5 \mathrm{NTU}$ for conventional or direct filtration) in at least $95 \%$ of the daily samples in any month. As of January 1, 2002, turbidity may never exceed 1 NTU, and must not exceed 0.3 NTU in $95 \%$ of daily samples in any month.

- HPC: No more than 500 bacterial colonies per milliliter.

- Long Term Enhanced Surface Water Treatment (Effective Date: January 14, 2005): Surface water systems or (GWUDI) systems serving fewer than 10,000 people must comply with the applicable Long Term 1 Enhanced Surface Water Treatment Rule provisions (e.g., turbidity standards, individual filter monitoring, Cryptosporidium removal requirements, updated watershed control requirements for unfiltered systems).

- Filter Backwash Recycling: The Filter Backwash Recycling Rule requires systems that recycle to return specific recycle flows through all processes of the system's existing conventional or direct filtration system or at an alternate location approved by the state.

- ${ }^{* *}$ More than $5.0 \%$ samples total coliform-positive in a month. (For water systems that collect fewer than 40 routine samples per month, no more than one sample can be total coliform-positive per month.) Every sample that has total coliform must be analyzed for either fecal coliforms or E. coli if two consecutive TC-positive samples, and one is also positive for E.coli fecal coliforms, system has an acute $\mathrm{MCL}$ violation. 
Table 2. EPA national primary drinking water standards for disinfectants.

\begin{tabular}{|c|c|c|}
\hline Contaminant & Maximum Contaminant Level Goal (mg/L) & Maximum Contaminant Level (mg/L) \\
\hline Chloramines (as $\mathrm{Cl}_{2}$ ) & MRDLG $=4^{*}$ & MRDL $=4.0^{* *}$ \\
\hline Chlorine $\left(\right.$ as $\left.\mathrm{Cl}_{2}\right)$ & MRDLG $=4^{*}$ & MRDL $=4.0^{* *}$ \\
\hline Chlorine dioxide (as $\left.\mathrm{ClO}_{2}\right)$ & MRDLG $=0.8^{*}$ & MRDL $=0.8^{* *}$ \\
\hline
\end{tabular}

*Maximum Residual Disinfectant Level Goal (MRDLG) - The level of a drinking water disinfectant below which there is no known or expected risk to health. MRDLGs do not reflect the benefits of the use of disinfectants to control microbial contaminants.

*Maximum Residual Disinfectant Level (MRDL) - The highest level of a disinfectant allowed in drinking water. There is convincing evidence that addition of a disinfectant is necessary for control of microbial contaminants.

Table 3. EPA national primary drinking water standards for disinfection byproducts.

\begin{tabular}{|l|c|c|}
\hline \multicolumn{1}{|c|}{ Contaminant } & $\begin{array}{c}\text { Maximum } \\
\text { Maximum Contaminant Level Goal } \\
(\mathbf{m g} / \mathbf{L})\end{array}$ & $\begin{array}{c}\text { Contaminant Level } \\
\text { (mg/L) }\end{array}$ \\
\hline Chlorite & 0.8 & 1.0 \\
\hline Haloacetic acids (HAA5) & $\mathrm{n} / \mathrm{a}^{*}$ & 0.060 \\
\hline Total Trihalomethanes (TTHMs) & $\mathrm{n} / \mathrm{a}^{*}$ & .08 \\
\hline
\end{tabular}

*Although there is no collective MCLG for this contaminant group, there are individual MCLGs for some of the individual contaminants:

- Trihalomethanes: bromodichloromethane (zero); bromoform (zero); dibromochloromethane (0.06 mg/L). Chloroform is regulated with this group but has no MCLG.

- Haloacetic acids: dichloroacetic acid (zero); trichloroacetic acid (0.3 mg/L). Monochloroacetic acid, bromoacetic acid, and dibromoacetic acid are regulated with this group but have no MCLGs.

Table 4. EPA national primary drinking water standards for inorganic chemicals.

\begin{tabular}{|l|c|c|}
\hline \multicolumn{1}{|c|}{ Contaminant } & Max. Contaminant Level Goal (mg/L) & Max. Contaminant Level (mg/L) \\
\hline Antimony & 0.006 & 0.006 \\
\hline Arsenic & $0^{*}$ & 0.010 (as of 01/23/06) \\
\hline $\begin{array}{l}\text { Asbestos } \\
\text { (fiber }>10 \text { micrometers) }\end{array}$ & 7 million fibers per liter & 2 \\
\hline Barium & 2 & 0.004 \\
\hline Beryllium & 0.004 & 0.005 \\
\hline Cadmium & 0.005 & 0.1 \\
\hline Chromium (total) & 0.1 & Action Level=1.3 \\
\hline Copper & 1.3 & 0.2 \\
\hline Cyanide (as free cyanide) & 0.2 & 4.0 \\
\hline Fluoride & 4.0 & Action Level=1.3 \\
\hline Lead & zero & 0.002 \\
\hline Mercury (inorganic) & 0.002 & 10 \\
\hline Nitrate (measured as Nitrogen) & 10 & 1 \\
\hline Nitrite (measured as Nitrogen) & 1 & 0.05 \\
\hline Selenium & 0.05 & 0.002 \\
\hline Thallium & 0.0005 & \\
\hline
\end{tabular}

${ }^{*}$ MCLGs were not established before the 1986 Amendments to the Safe Drinking Water Act. Therefore, there is no MCLG for this contaminant.

**Lead and copper are regulated by a Treatment Technique that requires systems to control the corrosiveness of their water. If more than $10 \%$ of tap water samples exceed the action level, water systems must take additional steps. For copper, the action level is $1.3 \mathrm{mg} / \mathrm{L}$, and for lead is $0.015 \mathrm{mg} / \mathrm{L}$. 
Table 5. EPA national primary drinking water standards for organic chemicals.

\begin{tabular}{|c|c|c|}
\hline Contaminant & Max. Contaminant Level Goal (mg/L) & Max. Contaminant Level (mg/L) \\
\hline Acrylamide & zero & Treatment Technology* \\
\hline Alachlor & zero & 0.002 \\
\hline Atrazine & 0.003 & 0.003 \\
\hline Benzene & zero & 0.005 \\
\hline Benzo(a)pyrene (PAHs) & zero & 0.0002 \\
\hline Carbofuran & 0.04 & 0.04 \\
\hline $\begin{array}{l}\text { Carbon } \\
\text { tetrachloride }\end{array}$ & zero & 0.005 \\
\hline Chlordane & zero & 0.002 \\
\hline Chlorobenzene & 0.1 & 0.1 \\
\hline $2,4-D$ & 0.07 & 0.07 \\
\hline Dalapon & 0.2 & 0.2 \\
\hline 1,2-Dibromo-3-chloropropane (DBCP) & zero & 0.0002 \\
\hline o-Dichlorobenzene & 0.6 & 0.6 \\
\hline p-Dichlorobenzene & 0.075 & 0.075 \\
\hline 1,2-Dichloroethane & zero & 0.005 \\
\hline 1,1-Dichloroethylene & 0.007 & 0.007 \\
\hline cis-1,2-Dichloroethylene & 0.07 & 0.07 \\
\hline trans-1,2-Dichloroethylene & 0.1 & 0.1 \\
\hline Dichloromethane & zero & 0.005 \\
\hline 1,2-Dichloropropane & zero & 0.005 \\
\hline Di(2-ethylhexyl) adipate & 0.4 & 0.4 \\
\hline Di(2-ethylhexyl) phthalate & zero & 0.006 \\
\hline Dinoseb & 0.007 & 0.007 \\
\hline Dioxin (2,3,7,8-TCDD) & zero & 0.00000003 \\
\hline Diquat & 0.02 & 0.02 \\
\hline Endothall & 0.1 & 0.1 \\
\hline Endrin & 0.002 & 0.002 \\
\hline Epichlorohydrin & zero & Treatment Technology* \\
\hline Ethylbenzene & 0.7 & 0.7 \\
\hline Ethylene dibromide & zero & 0.00005 \\
\hline Glyphosate & 0.7 & 0.7 \\
\hline Heptachlor & zero & 0.0004 \\
\hline Heptachlor epoxide & zero & 0.0002 \\
\hline Hexachlorobenzene & zero & 0.001 \\
\hline Hexachlorocyclopentadiene & 0.05 & 0.05 \\
\hline Lindane & 0.0002 & 0.0002 \\
\hline Methoxychlor & 0.04 & 0.04 \\
\hline Oxamyl (Vydate) & 0.2 & 0.2 \\
\hline $\begin{array}{l}\text { Polychlorinated } \\
\text { biphenyls (PCBs) }\end{array}$ & zero & 0.0005 \\
\hline Pentachlorophenol & zero & 0.001 \\
\hline Picloram & 0.5 & 0.5 \\
\hline Simazine & 0.004 & 0.004 \\
\hline Styrene & 0.1 & 0.1 \\
\hline
\end{tabular}




\begin{tabular}{|l|c|c|}
\hline \multicolumn{1}{|c|}{ Contaminant } & Max. Contaminant Level Goal (mg/L) & Max. Contaminant Level (mg/L) \\
\hline Tetrachloroethylene & zero & 0.005 \\
\hline Toluene & 1 & 0.003 \\
\hline Toxaphene & zero & 0.05 \\
\hline $2,4,5$-TP (Silvex) & 0.05 & 0.07 \\
\hline $1,2,4-$ Trichlorobenzene & 0.07 & 0.2 \\
\hline $1,1,1$-Trichloroethane & 0.20 & 0.005 \\
\hline $1,1,2-$ Trichloroethane & 0.003 & 0.005 \\
\hline Trichloroethylene & zero & 0.002 \\
\hline Vinyl chloride & zero & 10 \\
\hline Xylenes (total) & 10 & \\
\hline
\end{tabular}

*Each water system must certify, in writing, to the state (using third-party or manufacturer's certification) that when acrylamide and epichlorohydrin are used in drinking water systems, the combination (or product) of dose and monomer level does not exceed the levels specified, as follows:

- Acrylamide $=0.05 \%$ dosed at $1 \mathrm{mg} / \mathrm{L}$ (or equivalent).

- Epichlorohydrin $=0.01 \%$ dosed at $20 \mathrm{mg} / \mathrm{L}$ (or equivalent).

Table 6. EPA national primary drinking water standards for radionuclides.

\begin{tabular}{|l|c|c|}
\hline \multicolumn{1}{|c|}{ Contaminant } & Max. Contaminant Level Goal & Max. Contaminant Level \\
\hline Alpha particles & zero & 15 picocuries per Liter $(\mathrm{pCi} / \mathrm{L})$ \\
\hline Beta particles and photon emitters & zero & 4 millirems per year \\
\hline Radium 226 and Radium 228 (combined) & zero & $5 \mathrm{pCi} / \mathrm{L}$ \\
\hline Tritium & zero & $20,000 \mathrm{pCi} / \mathrm{L}$ \\
\hline Uranium & zero & $30 \mathrm{ug} / \mathrm{L}(\mathrm{as} \mathrm{of} \mathrm{12/08/03)}$ \\
\hline
\end{tabular}

\section{Storm water monitoring}

Under the National Pollutant Discharge Elimination System (NPDES) regulations, all facilities which discharge pollutants from any point source into waters of the United States (US) are required to obtain a permit. The NPDES storm water regulations cover the following classes of storm water dischargers: operators of municipal separate storm sewer systems (MS4s); industrial facilities in any of eleven identified categories that discharge to an MS4 or to a water of the US; and operators of certain construction activities. Storm water regulations are implemented by the EPA or authorized states.

NPDES permits may be issued as individual or general permits. In either case, NPDES permits generally require the development of a storm water pollution prevention plan, implementation of best management practices, and monitoring and reporting of storm water discharge data. Most industrial facilities elect coverage under a general permit because the permitting process is designed to be more efficient.

EPA has developed a multi-sector general permit (MSGP) for storm water dischargers, providing both general requirements and sector-specific requirements. The specific requirements apply to each of 30 industrial sectors and their associated subsectors. The current MSGP was published in the Federal Register on October 30, 2000 [8]. Authorized states may use alternative permits and/or may impose additional requirements.

Three types of monitoring may be required under the MSGP: visual examination, analytical monitoring, and compliance monitoring. Visual examinations are intended to provide a simple, inexpensive evaluation of storm water quality. Analytical monitoring is required for only specified 
subsectors, those which EPA has determined have a high potential to discharge a pollutant at concentrations of concern. For each of the identified subsectors, EPA has defined the parameters to be monitored and has established benchmark concentrations for each parameter. Analytical monitoring is required on a quarterly basis in year two of the permit; if these results exceed a benchmark value, a second round of analytical monitoring is required in year. Any time a benchmark concentration is exceeded, the facility must review their storm water pollution prevention plan to reduce pollutant loads.

Compliance monitoring is performed on an annual basis for certain storm water discharges subject to effluent guidelines. Some EPA regions require quarterly monitoring. The applicability of compliance monitoring is limited to the following discharges: landfill discharges; coal pile runoff; contaminated runoff from phosphate fertilizer manufacturing facilities; runoff from asphalt paving and roofing emulsion production areas; material storage pile runoff from cement manufacturing facilities; and mine dewatering discharges from crushed stone, construction sand and gravel, and industrial sand mines.

The MSGP analytical and compliance monitoring requirements are limited to discrete sampling events at specified intervals. Grab sampling is required. Authorized states may impose more extensive monitoring requirements.

\section{National pretreatment program monitoring}

Under the NPDES permitting program, EPA established the National Pretreatment Program to address "indirect discharges" into waters of the United States. Indirect discharges are discharges from industrial facilities to publicly owned treatment works (POTWs). The National Pretreatment Program requires dischargers to treat or control pollutants in their wastewater prior to discharge to the POTW. (The POTW is required to obtain an NPDES permit as a direct discharger.)

Under the General Pretreatment Regulations [9], all large POTWs, and some smaller POTWs with significant industrial discharges, must establish local pretreatment programs. The local pretreatment programs impose national pretreatment standards and requirements, as well as any more stringent local requirements.

EPA has established two general requirements for industrial dischargers prohibiting "interference" and "pass through." These requirements are designed to prevent damage to the treatment works and environmental harm downstream. In addition, EPA controls the discharge of 126 "priority pollutants," including metals and toxic organics.

Categorical pretreatment standards limit the discharge of specific pollutants; they are national standards for indirect dischargers in specific industrial categories. These standards are further categorized into pretreatment standards for existing sources (PSES) and pretreatment standards for new sources (PSNS). Currently, 32 industrial categories are subject to pretreatment standards. The standards may be expressed as concentration-based or mass-based, or both, depending upon the operational characteristics of the industry. Significant industrial users (SIUs) are required to monitor, at a minimum, on a semi-annual basis. Confirmatory sampling by the regulatory authority is required annually. Depending upon factors such as effluent variability, effluent impacts, and compliance history, the SIU may be required to sample more frequently. 
Table 7. Pretreatment standards for manufacturers of organic chemicals, plastics, and synthetic fibers $[10]$.

\section{Environmental Protection Agency}

\begin{tabular}{|c|c|c|}
\hline \multirow[b]{2}{*}{ Effluent characteristics } & \multicolumn{2}{|c|}{$\begin{array}{l}\text { BAT effluent limita- } \\
\text { tions and NSPS } 1\end{array}$} \\
\hline & $\begin{array}{l}\text { Maximum } \\
\text { for any } \\
\text { one day }\end{array}$ & $\begin{array}{c}\text { Maximum } \\
\text { for } \\
\text { monthly } \\
\text { average }\end{array}$ \\
\hline Anthracene ....... & 47 & 19 \\
\hline 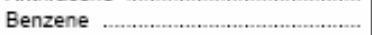 & 134 & 57 \\
\hline Benzo(a)anthracene ............ & 47 & 18 \\
\hline 3,4-Benzofluoranthene ....... & 48 & 20 \\
\hline Benzo(k)fluoranthene ........... & 47 & 18 \\
\hline Benzo(a)pyrene .................. & 48 & 20 \\
\hline Bis(2-ethylhexyl) phthalate ... & 258 & 95 \\
\hline Carbon Tetrachloride ............ & 380 & 142 \\
\hline Chlorobenzene & 380 & 142 \\
\hline Chloroethane & 285 & 110 \\
\hline Chloroform ......................... & 325 & 111 \\
\hline Chrysene & 47 & 19 \\
\hline Di-n-butyl phthalate .............. & 43 & 20 \\
\hline 1,2-Dichlorobenzene ............... & 794 & 196 \\
\hline 1,3-Dichlorobenzene .......... & 380 & 142 \\
\hline 1,4-Dichlorobenzene .......... & 380 & 142 \\
\hline 1,1-Dichloroethane ............... & 59 & 22 \\
\hline 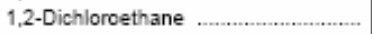 & 574 & 180 \\
\hline 1,1-Dichloroethylene & 60 & 22 \\
\hline 1,2-trans-Dichloroethylene ..................... & 68 & 25 \\
\hline 1,2-Dichloropropane ............. & 794 & 196 \\
\hline 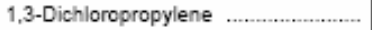 & 794 & 196 \\
\hline Diethyl phthalate & 113 & 46 \\
\hline 2,4-Dimethylphenol .............. & 47 & 18 \\
\hline 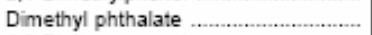 & 47 & 18 \\
\hline 4,6-Dinitro-o-cresol ...... & 277 & 78 \\
\hline 2,4-Dinitrophenol .................. & 4,291 & 1,207 \\
\hline 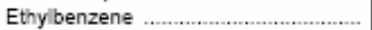 & 380 & 142 \\
\hline Fluoranthene .............. & 54 & 22 \\
\hline Fluorene & 47 & 19 \\
\hline Hexachlorobenzene ......... & 794 & 196 \\
\hline Hexachlorobutadiene ......... & 380 & 142 \\
\hline Hexachloroethane & 784 & 196 \\
\hline 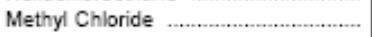 & 285 & 110 \\
\hline Methylene Chloride & 170 & 38 \\
\hline Naphthalene & 47 & 18 \\
\hline Nitrobenzene ..................... & 6.402 & 2,237 \\
\hline 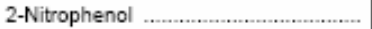 & 231 & 65 \\
\hline 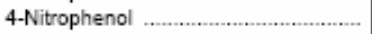 & 576 & 162 \\
\hline Phenanthrene & 47 & 19 \\
\hline 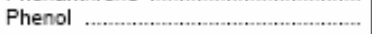 & 47 & 19 \\
\hline Pyrene & 48 & 20 \\
\hline Tetrachloroethylene & 184 & 52 \\
\hline 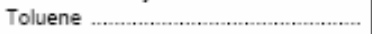 & 74 & 28 \\
\hline 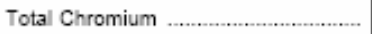 & 2,770 & 1.110 \\
\hline 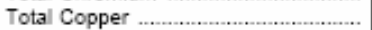 & 3,380 & 1.450 \\
\hline 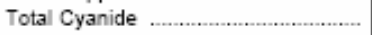 & 1,200 & 420 \\
\hline 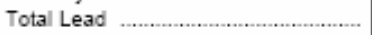 & 690 & 320 \\
\hline 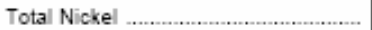 & 3,980 & 1,690 \\
\hline Total Zinc ${ }^{2}$ & 2,610 & 1,050 \\
\hline 1,2,4-Trichlorobenzene ........................... & 794 & 196 \\
\hline 1,1,1-Trichloroethane & 59 & 22 \\
\hline 1,1,2-Trichloroethane & 127 & 32 \\
\hline Trichloroethylene & 69 & 26 \\
\hline Vinyl Chloride & 172 & 97 \\
\hline
\end{tabular}

1 All units are micrograms per liter.

2 Total Zinc for Rayon Fiber Manufacture that uses the viscose process and Acrylic Fibers Manufacture that uses the zinc chloride/solvent process is $6.796 \mu \mathrm{g} /$ and $3.325 \mu \mathrm{g} / \mathrm{l}$ for maximum for any one day and maximum for monthly average. respectively.

The type of industry regulated under the pretreatment program is wide-ranging, including grain mills, feedlots, electroplating facilities, iron and steel manufacturers, and fertilizer manufacturers. For many industries, the monitoring required is limited to several effluent characteristics, such as biological effluent demand, total suspended solids, and $\mathrm{pH}$. For other industries monitoring of a select set of priority pollutants, such as a specified subset of metals, is required. In a few instances, monitoring of all priority pollutants is required. Pretreatment standards for indirect discharges from manufacturers of organic chemicals, plastics, and synthetic fibers are provided in Table 7. 


\section{Ambient air quality}

A number of substances are identified as hazardous air pollutants (now termed "toxic air pollutants" by EPA) under the Clean Air Act and are regulated under the National Emission Standards for Hazardous Air Pollutants program. The American Conference of Governmental Industrial Hygienists (ACGIH) established airborne concentration limits called Threshold Limit Values (TLV) of various hazardous air pollutants. The TLVs are believed to represent conditions under which nearly all workers could be exposed day after day without adverse health effects. The TLVs are based on information from industrial experience and experimental studies on humans and animals. Table 8 lists a few hazardous air pollutants (HAP) and the associated ACGIH TLVs. Additional information on these compounds can be found from the following web sites:

- www.epa.gov/ttn/atw/hlthef/benzene.html

- www.epa.gov/ttn/atw/hlthef/xylenes.html

- www.epa.gov/ttn/atw/hlthef/tri-ethy.html

Table 8. Threshold Limit Values for several hazardous air pollutants [11].

\begin{tabular}{|c|c|c|}
\hline \multirow{2}{*}{$\begin{array}{c}\text { Hazardous Air } \\
\text { Pollutant }\end{array}$} & Threshold Limit Value (ppm) \\
\cline { 2 - 3 } & 8-Hour Time Weighted Average & $\begin{array}{c}\text { 15-Minute Short-Term } \\
\text { Exposure Limit }\end{array}$ \\
\hline Benzene & 0.5 & 2.5 \\
\hline Xylenes & 100 & 150 \\
\hline Trichloroethylene & 50 & 100 \\
\hline
\end{tabular}

In 1998, the City of Albuquerque adopted a policy for regulating emissions from industries. An analysis for each relevant HAP at a site is performed to determine if the emissions from the stack result in an exceedance of the ACGIH TLV for any of the relevant substances. If the ACGIH TLV at the stack is exceeded, the concentration of that substance must be analyzed at the "fence line" (i.e., property boundary). The concentration at the fence line should not exceed $1 / 100^{\text {th }}$ the ACGIH TLV. For any HAP that has uncontrolled emissions which result in an exceedance of the ACGIH TLV at the stack and $1 / 100^{\text {th }}$ of the ACGIH TLV at the fence line, air-pollution controls will be required to reduce the concentrations to $1 / 100^{\text {th }}$ the TLV at the fence line. An air quality permit will also be required to ensure proper operation of the control equipment.

Additional air quality standards have been compiled from 20.11.1 NMAC - Title 20, Environmental Protection - Chapter 11, Albuquerque/Bernalillo county Air Quality Control Board - Part 1 General Provisions (see Table 9). 
Table 9. Enforceable standards for various air pollutants.

\begin{tabular}{|c|c|c|c|c|}
\hline \multirow[t]{2}{*}{ Pollutant } & \multirow{2}{*}{$\begin{array}{c}\text { Goals } \\
\text { Albuquerque }\end{array}$} & \multicolumn{3}{|c|}{ Enforceable Standards } \\
\hline & & New Mexico State & Federal Primary & Federal Secondary \\
\hline \multicolumn{5}{|l|}{ Carbon Monoxide (CO) } \\
\hline 8-hour average & --- & 8.7 ppm & 9.0 ppm & 9.0 ppm \\
\hline 1-hour average & $13 \mathrm{ppm}$ & $13.1 \mathrm{ppm}$ & $35 \mathrm{ppm}$ & $35 \mathrm{ppm}$ \\
\hline \multicolumn{5}{|l|}{ Nitrogen Dioxide $\left(\mathrm{NO}_{2}\right)$} \\
\hline 24-hour average & .062 ppm & 10 ppm & --- & --- \\
\hline Annual arithmetic mean & .053 ppm & .05 ppm & $.053 p p m$ & .053 ppm \\
\hline \multicolumn{5}{|l|}{ Ozone $\left(\mathrm{O}_{3}\right)$} \\
\hline 1-hour average & .120 ppm & --- & .120 ppm & .120 ppm \\
\hline \multicolumn{5}{|l|}{ Sulfur Dioxide $\left(\mathrm{SO}_{2}\right)$} \\
\hline 24-hour average & .10 ppm & .10 ppm & --- & .140 ppm \\
\hline 3-hour average & --- & --- & --- & $.5 \mathrm{ppm}$ \\
\hline Annual arithmetic mean & .004 ppm & .02 ppm & .03 ppm & --- \\
\hline \multicolumn{5}{|l|}{ Particulate Matter $\left(\mathrm{PM}_{10}\right)$} \\
\hline 24-hour average & $150 \mu \mathrm{g} / \mathrm{m}^{3}$ & --- & $150 \mu \mathrm{g} / \mathrm{m}^{3}$ & --- \\
\hline Annual arithmetic mean & --- & --- & --- & $50 \mu \mathrm{g} / \mathrm{m}^{3}$ \\
\hline \multicolumn{5}{|l|}{ Lead $(\mathrm{Pb})$} \\
\hline Quarterly arithmetic mean & $1.5 \mu \mathrm{g} / \mathrm{m}^{3}$ & --- & $1.5 \mu \mathrm{g} / \mathrm{m}^{3}$ & $1.5 \mu \mathrm{g} / \mathrm{m}^{3}$ \\
\hline \multicolumn{5}{|l|}{ Hydrogen Sulfide } \\
\hline 1-hour average & .003 ppm & .010 ppm & --- & --- \\
\hline \multicolumn{5}{|l|}{ Total Reduced Sulfur } \\
\hline $1 / 2$ hour average & --- & .003 ppm & --- & --- \\
\hline 1-hour average & .003 ppm & --- & --- & --- \\
\hline \multicolumn{5}{|l|}{ Particulate Matter (TSP) } \\
\hline 24-hour average & $150 \mu \mathrm{g} / \mathrm{m}^{3}$ & $150 \mu \mathrm{g} / \mathrm{m}^{3}$ & --- & --- \\
\hline 7-day average & --- & $110 \mu \mathrm{g} / \mathrm{m}^{3}$ & --- & --- \\
\hline 30-day average & --- & $90 \mu \mathrm{g} / \mathrm{m}^{3}$ & --- & --- \\
\hline Annual geometric mean & $60 \mu \mathrm{g} / \mathrm{m}^{3}$ & $60 \mu \mathrm{g} / \mathrm{m}^{3}$ & --- & -- \\
\hline
\end{tabular}

\section{Sensor technologies for environmental monitoring}

The purpose of this section is to identify and describe sensor technologies (with an emphasis on Sandia-developed technologies) that may be applicable to monitoring various contaminants described in the previous sections. The technologies are organized according to analyte, which include trace metals, radioisotopes, volatile organic compounds, and biological pathogens. The sensor technologies are described briefly, and then tables summarizing features and specifications (e.g., sensitivity, size, speed, etc.) of each sensor technology are presented in Table 10 through Table 13 in the section "Summary and specifications of sensor technologies". 


\section{Trace metal sensors}

-Nanoelectrode array

Nanoelectrode arrays have been fabricated to identify and quantify dissolved metals [12-13]. Signals from the electrodes are obtained by monitoring current and voltage during application of an electrical potential. Approximately 1 million individual electrodes can be placed on a 1 square inch substrate using electron-beam lithography or chemical vapor deposition. The sensing electrodes are integrated with the reference electrode, eliminating the need for buffers and permitting noncontaminating sensing in ultra-pure water. The small electrode size coupled with a very high density produces a signal with up to $10^{3}$ times better signal-to-noise ratio than standard electrodes. Using multiple electrodes, coatings, and electrochemical techniques, target analytes can include toxic industrial chemicals and metals, such as trichloroethylene, methyl-t-butyl ether, arsenic, lead, and chromium.

\section{-Laser-induced breakdown spectroscopy (LIBS)}

As its name implies, LIBS uses a laser to rapidly heat a very small area (usually solid or liquid), generating a plasma from the atomic constituents present at the focal point. Radiative relaxation of the plasma is then observed using sensitive spectroscopic instrumentation (see Figure 1). LIBS is also known as Laser Spark Spectroscopy (LASS).

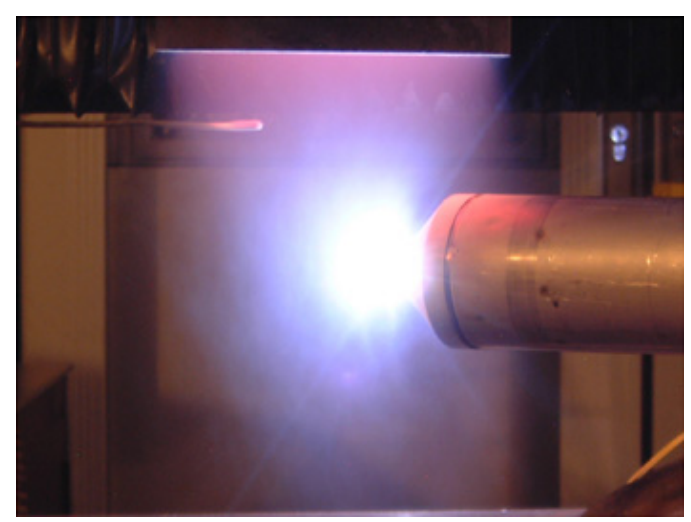

Figure 1. Stand-off LIBS probe head. Laser ablation energy and spectroscopic collection occurs through fiber optics.

LIBS can be used for rapid analysis of hazardous metals and other inorganic contaminants in water, soil, and mixed waste sites [14-15]. It can be used to detect almost all elements, though certain metals exhibit orders of magnitude greater emission. Detection limits are a function of each specific metal, and the spectroscopic and detector hardware. Low ppb levels are typical. Contaminants targeted in Sandia projects include $\mathrm{As}, \mathrm{Be}, \mathrm{Hg}, \mathrm{Se}, \mathrm{Pb}, \mathrm{Cd}, \mathrm{Cu}, \mathrm{Zn}, \mathrm{Ag}, \mathrm{Cr}, \mathrm{Fe}$, and Mn. Recently, a LIBS system was set up for measuring metal emissions in the waste streams of a thermal treatment facility [16]. Currently, a field deployable LIBS system is configured at Sandia-Livermore employing an image intensified CCD array, which provides sufficient signal intensity for single laser pulse LIBS. Delivery of the laser light to remote location via a fiber-optic cable has been performed. Spectral emission 
likewise can be readily be transported over hundreds of feet for analysis [15]. LIBS can be extended to biodetection by looking for rapid, temporal increases in the presence and/or ratios of $\mathrm{Ca}, \mathrm{Na}, \mathrm{K}$.

-Miniature chemical flow probe sensor

The miniature chemical flow-probe sensor can detect metals, especially copper. See "Miniature chemical flow probe sensor" below for details (page 19).

\section{Radioisotope sensors}

\section{RadFET (Radiation field-effect transistor)}

The RadFET concept for measuring gamma radiation dose has been around for many years. It is based on ionizing radiation permanently promoting high mobility electrons into low mobility holes. This creates an irreversible shift in the FET's threshold voltage. Sandia has microfabricated miniature RadFETs [17]. Sensitivities depend in part upon fabrication structure, and range from 0.01 to $5 \mathrm{mV}$ per rad. An energy spectrometer can be made by fabricating filters of varying threshold energies on RadFET arrays (Figure 2). With consideration of threshold barriers, RadFETs are universal ionizing radiation detectors. The sensitivity of RadFETs increases with application of increasing bias voltage. However Sandia has fabricated designs that are moderately sensitive with no voltage source.
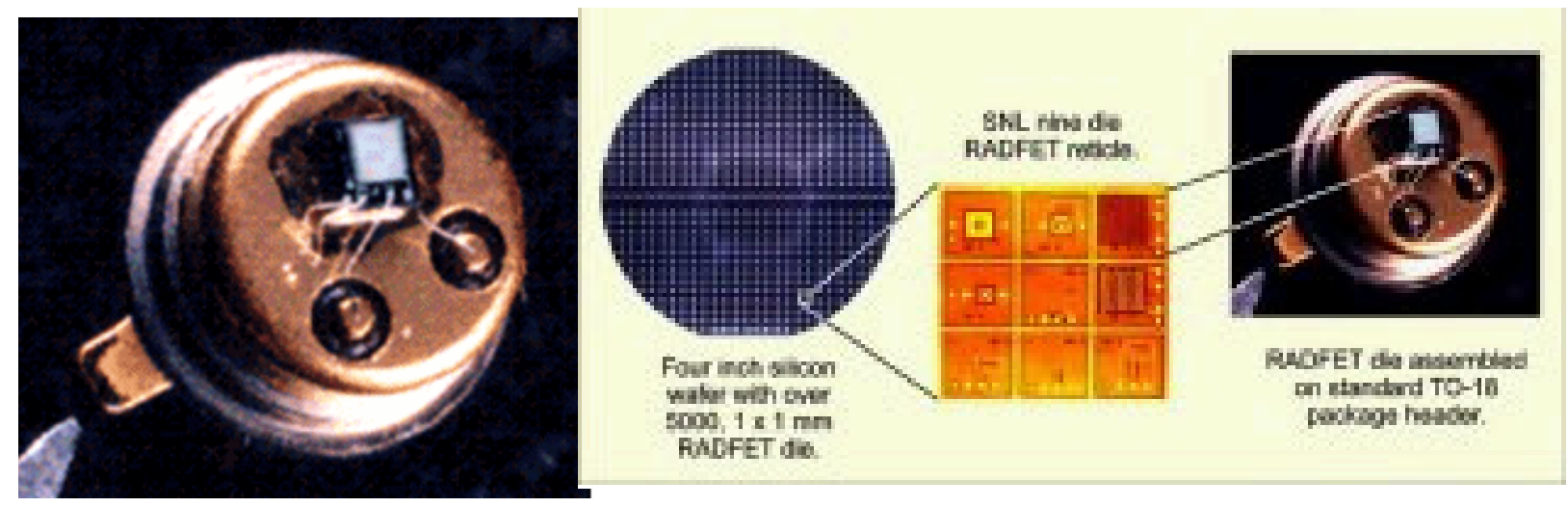

Figure 2. The $1 \mathrm{~mm}^{2}$ RadFET element fits on a standard TO-18 package header. Over 5000 RadFETs can be microfabricated on a single 4 inch wafer.

Cadmium zinc telluride (CZT) detectors

CZTs are semiconductor gamma and neutron radiation detectors, producing current flow under the influence of a gate voltage, upon exposure to high energy radiation. They can be fabricated in arrays to perform imaging or spectroscopy [18] (see Figure 3). While these are promising and sensitive sensors, their performance, and thus calibration, degrades with cumulative exposure. Long term performance is hard to track, as damage may be progressive with radiation energy levels [19]. Sandia performed experiments to improve the fabrication process for industry (see also Figure 3). Commercial sensors and spectrometers are available from EV Products or AmpTek. 

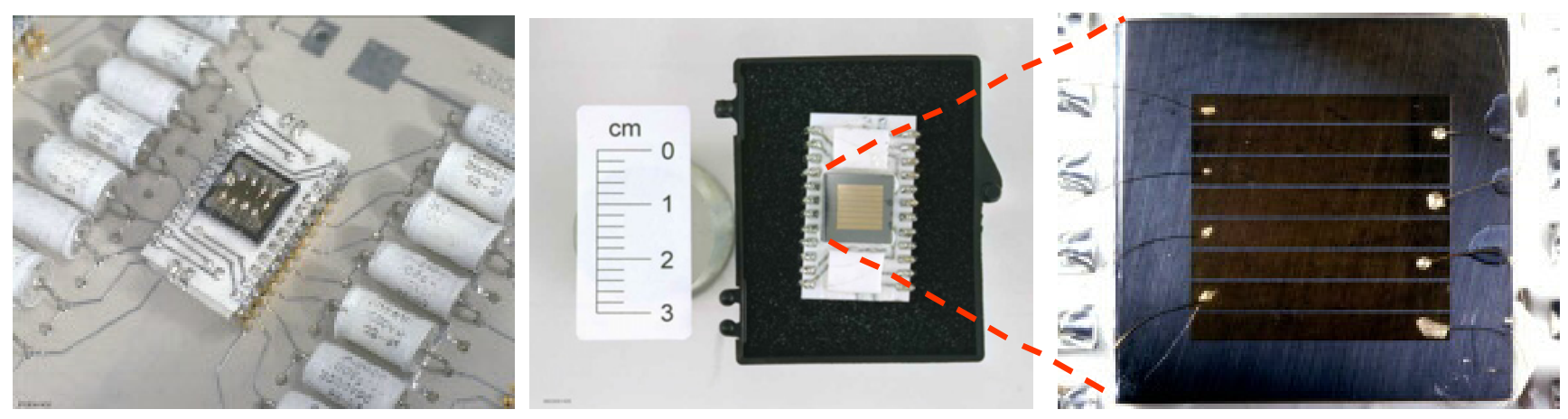

Figure 3. The $1 \mathrm{~cm}^{2} \mathrm{CZT}$ array sits on a dip package on a circuit board for a handheld gamma radiation spectrometer.

-Low-energy pin diodes beta spectrometer

A handheld low-energy beta spectrometer was assembled at Sandia for detecting tritium contamination using commercially available pin photodiodes from Hamamatsu [20]. The system works by measuring current pulses generated in the diode when beta particles strike. Electronic circuits convert each signal to a voltage pulse whose amplitude is proportional to the energy of the particle.

-Thermoluminescent dosimeter (TLD)

A thermoluminescent dosimeter is a crystal that absorbs energy from radiological exposure, semipermanently promoting electrons into semiconductor holes. Upon heating the crystal, the trapped energy is released in the form of light. A TLD reader uses a photodetector to convert the signal into a radiation dose reading. Commonly used crystals are calcium fluoride-manganese and lithium fluoride. Sandia has fabricated TLDs with crystals implanted in Teflon to improve sensitivity [21-22]. Thin crystals can be used to measure low energy radiation, while thick crystals measure total exposure. Filters and different crystal types can also be used for energy discrimination.

-Isotope identification gamma detector

An isotope identification gamma detector was developed in conjunction with the Defense Threat Reduction Agency, Northrup Grumman, Applied Research Associates, and DOE/NNSA laboratories. This was designed as a portal instrument to find and identify unconventionally transported nuclear weapons and radiological dispersal devices.

-Neutron generator for nuclear material detection

A small neutron generator is being developed for use in probing for the presence of nearby nuclear materials [23]. The meter-tall instrument interrogates nuclear material by "pinging" it with neutrons to incite the release of secondary particles. These particles, which are indicative of their atomic source, are then detected. The smaller prototype will be tested soon.

-Non-sandia radiation detectors

Commonly used gamma radiation detectors include high purity germanium (require liquid nitrogen), and scintillation crystals such as thallium-doped sodium iodide (low energy resolution). 
Geiger counters were one of the first radiation detectors available, and the first to provide quantitative measurements of radiation. They use very simple electronics and cover a wide radiation range, but they are bulky compared to some of the sensors described above.

Commercial options: Radiation Experiments and Monitors (REM) makes a commercial radiation FET sensor with a sensitivity of $-10 \mathrm{mV} / \mathrm{rad}$ when biased to $+20 \mathrm{~V}$. TLDs can be purchased from Teledyne Isotopes. CZT detectors can be purchased from Mitsubishi Electric and Communication Electronics, Inc. (Ann Arbor, MI). Geiger counters can be purchased from Mineralab (Prescott, AZ).

\section{Volatile organic compound sensors}

\section{-Evanescent fiber-optic chemical sensor}

An evanescent wave is the energy that penetrates a dielectric interface when electromagnetic radiation undergoes total internal reflection. This wave can interact with matter within the penetration depth. By using specialized coatings as the fiber-optic cladding, chemical species can be preferentially concentrated from a matrix into the evanescent interaction zone. Polymer optical wave guides have been used for sensing organic compounds in aqueous solutions at low ppm levels [24]. $\mathrm{pH}$ measurements can be made using sol-gel coatings. For sensing applications, near infrared (NIR) spectroscopy is used for quantitative measurements. With excellent light transmission in this region, sensing can be performed over great distances. However, the spectroscopic signal from mixtures must be deconvolved using multivariate analysis.

\section{-Grating light reflection spectroelectrochemistry}

Grating light reflection spectroscopy (GLRS) is a technique for spectroscopic analysis and sensing. A transmission diffraction grating is placed in contact with a liquid sample to be analyzed, and an incident light beam is directed onto the grating. At certain angles of incidence, some of the diffracted orders are transformed from traveling waves to evanescent waves. This occurs at a specific wavelength that is a function of the grating period and the complex index of refraction of the sample. The intensity of a diffracted order is also dependent upon the sample's complex index of refraction. The real part of the theoretical equations correspond to the speed of light in the material, and the imaginary part corresponds to light absorption. This technique was used at Sandia in combination with electrochemical modulation of a gold-coated metallic spectroscopic grating for the detection of trace amounts of aromatic hydrocarbons [25]. The grating was configured as the working electrode in an electrochemical cell containing water plus trace amounts of TNT and a dye. Cyclic electrochemical modulation produced lower limits of detection, 50 parts per million and 50 parts per billion, respectively.

-Miniature chemical flow probe sensor

This down-hole probe is designed to measure organic analytes diffusing through a semi-permeable membrane [15]. The analytes react with a reagent, forming spectrally distinct products. Absorption bands from a flash lamp are then observed with a spectrometer system, using fiber-optics to carry the light in both directions. Target analytes can be volatile organic compounds in air or water (particularly chlorinated halocarbons), or dissolved metals (copper gives particularly strong response). 


\section{-SAW chemical sensor arrays}

An acoustic sensor is typically used by measuring a decrease in its active resonant frequency that is related to trace mass loading on the active surface (Figure 4). Polymers, sol-gels, and high surface area coatings are often applied to enhance mass absorption/adsorption, and to provide a degree of chemical class selectivity. Acoustic sensors used at Sandia include flexural plate wave (FPW) sensors, quartz crystal microbalances (QCM), and surface acoustic wave (SAW) sensors. By placing coatings of various chemical properties on a 6-SAW array, chemical speciation and quantification of vapors have been performed [26]. In one test the responses of these materials to each of 14 different analytes, representing the classes of saturated alkane, aromatic hydrocarbon, chlorinated hydrocarbon, alcohol, ketone, organophosphonate, and water, was evaluated. The results revealed a qualitative "chemical orthogonality" of the films useful for pattern recognition analysis. SAWs are the most sensitive of the above-mentioned acoustic sensors, and a number of technological advances have been made to facilitate their use in other chemical systems. Perhaps the most important of these advances is an ASIC (application specific integrated circuit) that converts DC power to the required high frequency impulse, and a reverse conversion for monitoring the frequency shift as a proportional DC shift [27].

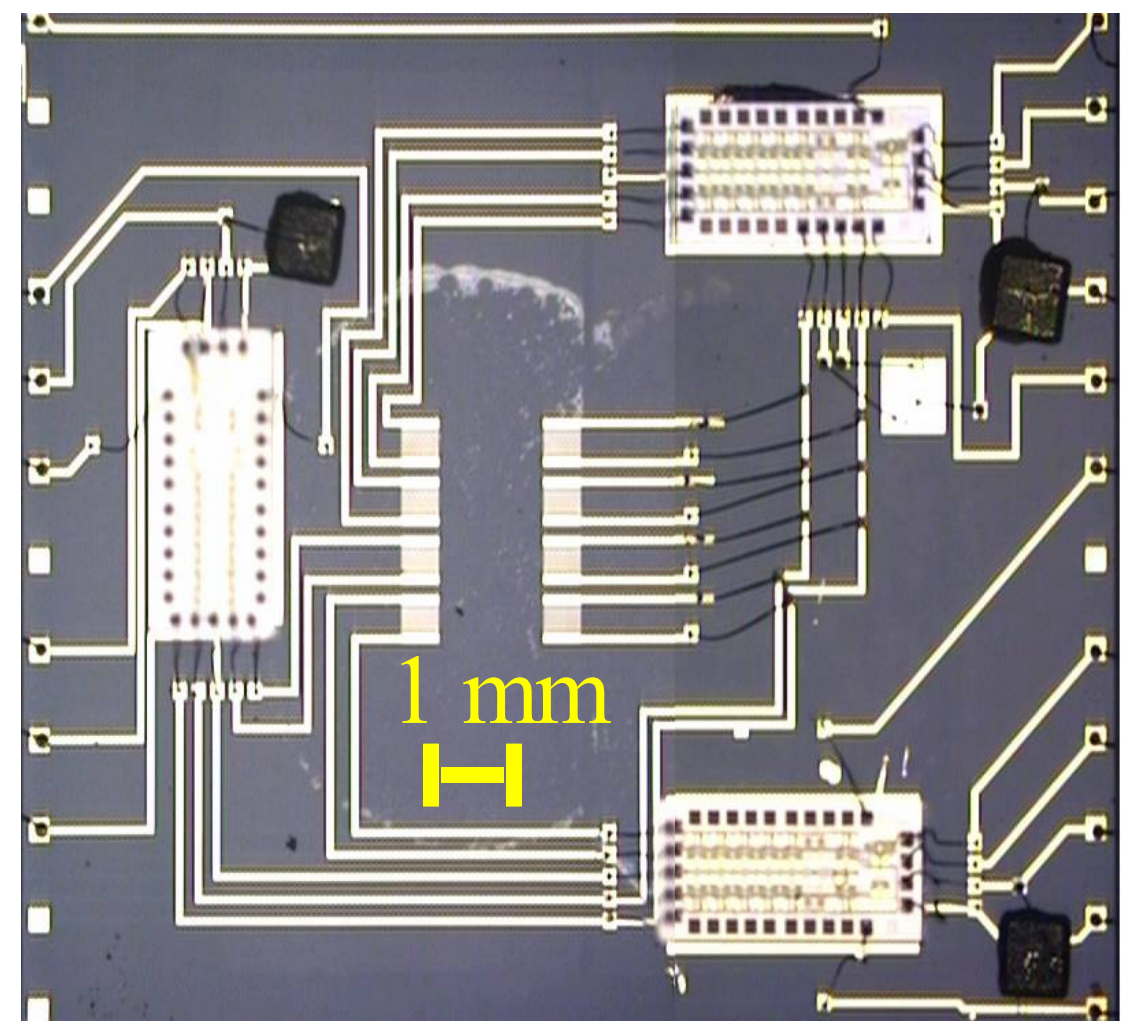

Figure 4. Four SAW sensor elements aligned vertically on an application specific integrated circuit. One delay line is left uncoated to compare frequency shifts of the other polymer or sol-gel coated lines.

\section{-MicroChemLab (gas phase)}

The gas phase MicroChemLab is a miniature gas chromatography (GC) system originally designed for chemical warfare agent detection for national security needs. Due to the high versatility of GC it has widespread utility. The MicroChemLab can likewise be configured for a variety of applications, 
including quantification of organic compounds from natural gas to explosives to derivatized biological fatty acids. The main components typically consist of a microfabricated hotplate preconcentrator (PC), a micromachined silicon gas chromatography column $(\mu \mathrm{GC})$, and a surface acoustic wave (SAW) sensor array [28]. The PC uses absorbent sol-gels, polymers, or a high surface area adsorbent solid phase. The low heat capacity membrane is then heated to hundreds of degrees in milliseconds to desorb collected analyte. This serves as the injection mechanism for the $\mu \mathrm{GC}$. The $\mu \mathrm{GC}$ separates the injected chemicals in elution time through differing retention capacities with the polymer coated wall or solid packing materials. The chemicals are then detected in order by the SAW sensor.

To address the different nature of the various applications, several variations in components exist. For highly volatile compounds (methane, carbon dioxide) an injection loop is commonly used. A Sandia microfabricated version does not yet exist. A variety of sensors are also in various stages of development, each with advantages and disadvantages. These include a thermal conductivity detector, micro-pellistor array, gold nanowire sensor, and a nitrogen-phosphorous detector.

\section{-Gold nanoparticle chemiresistors}

Gold nanoparticle chemiresistors rely on the general ohmic sensing principles behind other chemiresistors with a few differences. In this sensor, the gold nanoparticles are electrically connected through conductive polymer linkages. While the conduction system is structurally bound in a second, nonconductive polymer, polymer swell minimally affects the resistive measurement. A more stable, reproducible, and sensitive signal is obtained from the direct interaction of analytes with the polarizable polymer links. Thus, films can be significantly thinner and detect lesser concentrations. To date, the sensors have measured $\mathrm{pH}$ and other ion concentrations in liquids (personal communication, D. Wheeler, Sandia National Laboratories, April 1, 2004). Outside researchers have primarily focused on gas phase VOCs, which is the next target of the Sandia sensor.

-Electrical impedance of tethered lipid bilayers on planar electrodes

This sensor consists of a very thin layer of lipid bilayers. VOCs adsorbing or absorbing into the layer changes ion mobility in the structure. This may offer orders of magnitude increase in sensitivity over existing polyelectrolyte coated capacitive chemiresistors. The large increase in sensitivity arises from molecular recognition elements, like antibodies that bind the analyte molecules.

\section{-MicroHound}

The MicroHound is a complete analytical system consisting of a chemical preconcentration system and a miniature Ion Mobility Spectrometer (IMS) [29]. Designed primarily for explosives, it can be modified for detecting semi-volatile organic compounds in air. The preconcentration system draws large volumes of air through a mesh screen that selectively adsorbs explosives. The screen is then rapidly heated to desorb the chemicals as a pulse into the inlet of the IMS. The IMS ionizes chemicals at the time-gated entrance of a drift tube. The ions are electrostatically driven against a counterflowing inert gas to a sensing electrode. Ions are separated from each other in the drift tube according to size, with smaller chemicals arriving first. Identification and quantification are determined by drift time and peak size, respectively. 


\section{-Hyperspectral imaging}

Multiple infrared images of the same location (microscopic or macroscopic) are obtained using different filters. Thus, a color spectrum of each pixel is obtained. These multidimensional images can be processed for quantitative species mapping [30]. This is a stand-off method and could be used from a UAV or satellite for surface soil monitoring. These methods have also been used for biological and biomedical applications [31].

\section{-Chemiresistor array}

The chemiresistor sensor is a chemically sensitive resistor comprised of a conductive polymer film deposited on a micro-fabricated circuit [32]. The chemically-sensitive insulating polymer is dissolved in a solvent and mixed with conductive carbon particles. The resulting ink is then deposited and dried onto thin-film, parallel, non-intersecting platinum traces on a solid substrate (chip). When chemical vapors come into contact with the polymers, the chemicals absorb into the polymers, causing them to swell. The swelling changes the physical conformation of the conductive particles in the polymer film, thereby changing the electrical resistance across the platinum-trace electrodes, which can be measured and recorded using a data logger or an ohmmeter. The swelling is reversible if the chemical vapors are removed, but some hysteresis can occur at high concentration exposures. The amount of swelling corresponds to the concentration of the chemical vapor in contact with the chemiresistor, so these devices can be calibrated by exposing the chemiresistors to known concentrations of target analytes.

The architecture of the microsensor integrates an array of chemiresistors with a temperature sensor and heating elements [33]. The chemiresistor array has been shown to detect a variety of VOCs including aromatic hydrocarbons (e.g., benzene), chlorinated solvents (e.g., trichloroethylene (TCE), carbon tetrachloride), aliphatic hydrocarbons (e.g., hexane, iso-octane), alcohols, and ketones (e.g., acetone). The on-board temperature sensor comprised of a thin-film platinum trace can be used to not only monitor the in-situ temperature, but it can also be used in a temperature control system. A feedback control system between the temperature sensor and on-board heating elements can allow the chemiresistors to be maintained at a fairly constant temperature, which can aid in the processing of data when comparing the responses to calibrated training sets. In addition, the chemiresistors can be maintained at a temperature above the ambient to prevent condensation of water, which may be detrimental to the wires and surfaces of the chemiresistor.

A robust package has been designed and fabricated to house the chemiresistor array [34]. This cylindrical package is small ( $\sim 3 \mathrm{~cm}$ diameter) and is constructed of rugged, chemically-resistant material. Early designs have used PEEK (PolyEtherEtherKetone), a semi-crystalline, thermoplastic with excellent resistance to chemicals and fatigue. Newer package designs have been fabricated from stainless steel (Figure 5). The package design is modular and can be easily taken apart (unscrewed like a flashlight) to replace the chemiresistor sensor if desired. Fitted with Viton O-rings, the package is

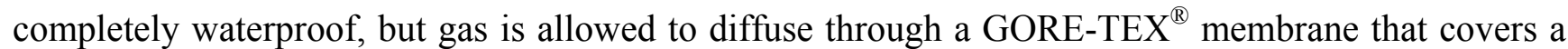
small window to the sensor. Like clothing made of GORE-TEX ${ }^{\circledR}$, the membrane prevents liquid water from passing through it, but the membrane "breathes," allowing vapors to diffuse through. Even in water, dissolved VOCs can partition across the membrane into the gas-phase headspace next to the chemiresistors to allow detection of aqueous-phase contaminants. The aqueous concentrations can be 
determined from the measured gas-phase concentrations using Henry's Law. Mechanical protection is also provided via a perforated metal plate that covers the chemiresistors. The chemiresistors are situated on a 16-pin dual-in-line package that is connected to a weatherproof cable, which can be of any length because of the DC-resistance measurement. The cable can be connected to a hand-held multimeter for manual single-channel readings, or it can be connected to a multi-channel data logger for long-term, remote operation.

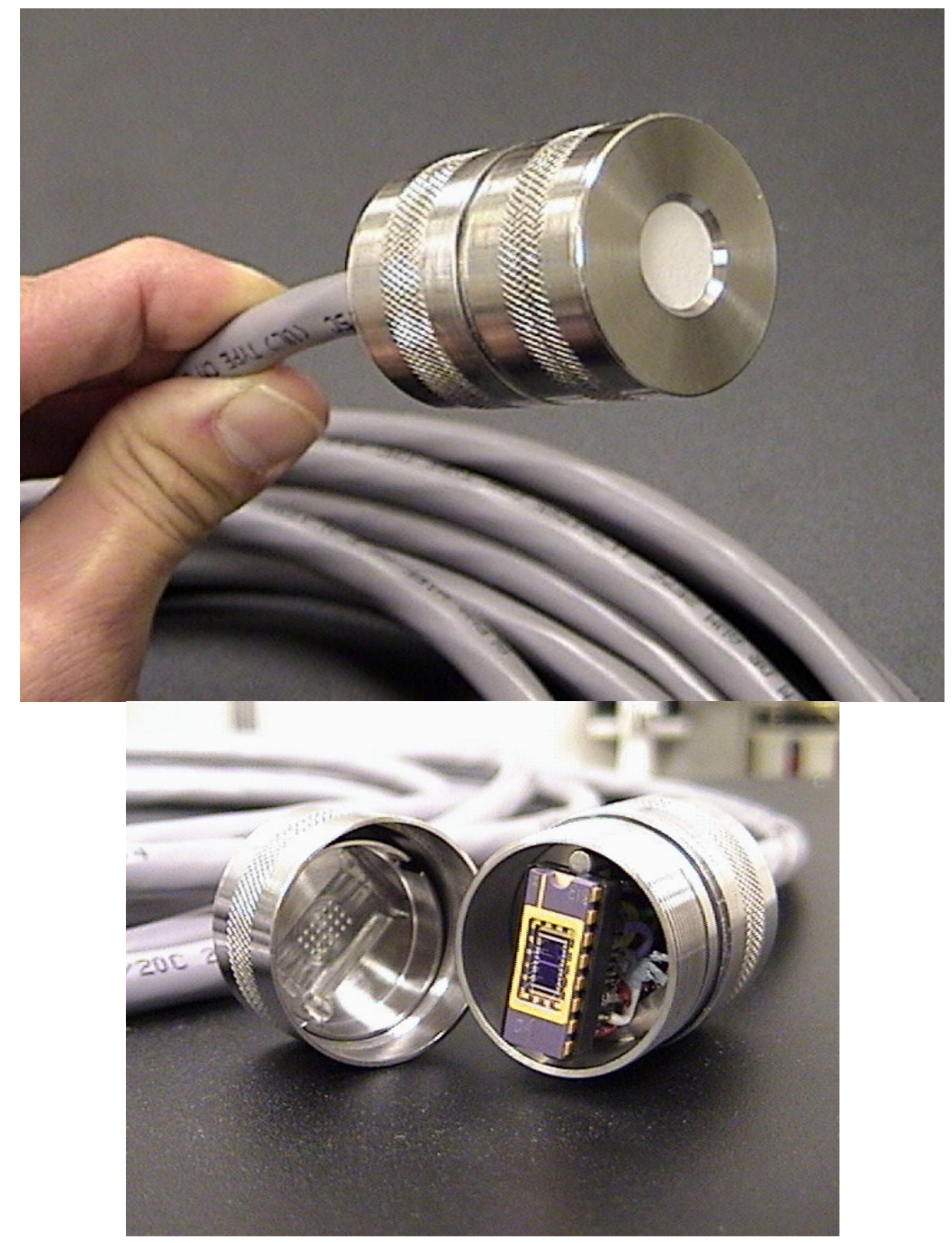

Figure 5. Stainless-steel waterproof package that houses the chemiresistor array. Left: GORE-TEX ${ }^{\circledR}$ membrane covers a small window over the chemiresistors. Right: Disassembled package exposing the 16-pin dual-in-line package and chemiresistor chip.

\section{Biological sensors}

-Fatty acid methyl esters (FAME) analyzer

This method uses microhotplates and micro-chromatography columns ( $\mu \mathrm{GC}$ ) from the MicroChemLab to analyze whole biological cells [35]. A liquid sample is placed on the hotplate along with a methylating agent. When the hotplate is thermally ramped (to $500^{\circ} \mathrm{C}$ in tens of milliseconds) the 
cells are lysed with proteins in the lipid bilayer forming semi-volatile FAMEs. This also served as the injection mechanism into a $\mu \mathrm{GC}$, where the FAMEs were separated for identification and quantification. The ratios of the FAMEs can be used to distinguish bacteria at the gram-type, genera, and even species level with high-resolution instrumentation. Sandia work aimed at miniaturizing halfmillion dollar bench scale instrumentation down to a handheld, battery-powered instrument with minimal sample preparation. Target analytes include biological warfare agents, food contaminants, and other toxic pathogens.

\section{-iDEP (insulator-based dielectrophoresis)}

This technique uses an electric field applied across a microfabricated array of insulating posts [36]. The polypropylene device selectively preconcentrates particles based on their polarizability and size (Figure 6). It can be used to preconcentrate proteins for analysis in the liquid MicroChemLab or other systems for fingerprint identification of pathogens.

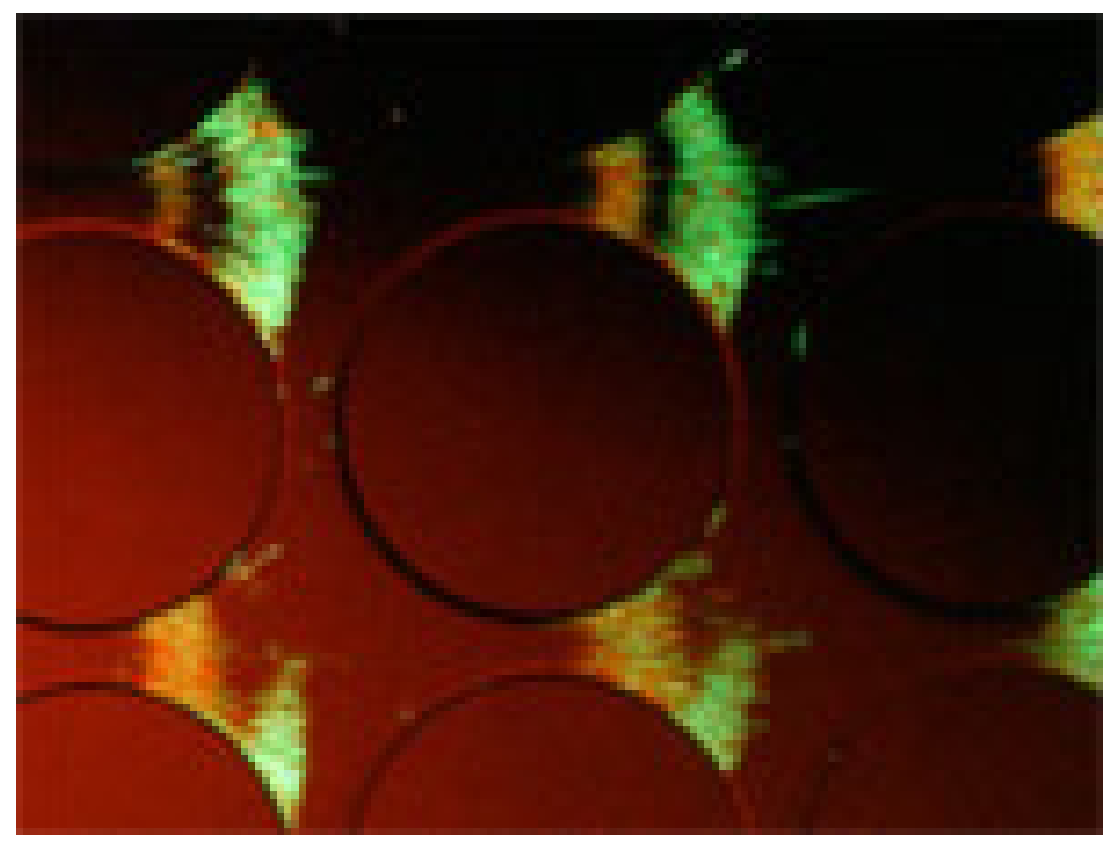

Figure 6. Electric field gradients created between microfabricated posts separate fluorescently tagged live and dead E. coli while dielectrophoretically concentrating them in zones.

\section{-Bio-SAW sensor}

Acoustic sensors are typically used by measuring a decrease in their resonant frequency that is related to mass loading. Biological detection can be performed by applying specific antibody coatings to the active surface of the acoustic device (Figure 7). Anthrax spores can be detected in a few minutes, and other biological threats can be detected using other antibody coatings [37]. An array of sensors with different coatings would provide increased versatility.

$-\mu$ ProLab

This LDRD Grand Challenge system is being designed for preconcentration and analysis of proteins and peptides using MIMS (molecular integrated microsystems) [38]. This architecture will 
take the advantages inherent in system miniaturization to a higher level of performance. At the same time, simplicity of production is sought. Successes to date include cast-in-place fluidic structures and coatings, and the ability to preconcentrate protein and peptide signatures 1000 fold using programmable switchable polymers and electrokinetic trapping.

\section{-MicroChemLab (Liquid)}

The liquid MicroChemLab is the counterpart to the gas-phase MicroChemLab above [39]. It is a hand-portable, low-power instrument designed to detect a broad range of chemical and biological agents in less than five minutes. The detector uses capillary electrophoresis with three analysis trains: 1) DNA analysis to identify bacteria and viruses, 2) immunoassays to identify bacteria, viruses, toxins, and 3) protein signatures to identify toxins. Fluid handling is contained to micromachined channels on a single board, and driven by high voltage, but low power, electrokinetic forces. Sample preconcentration and injections occur through manipulation of the electrophoretic fields without the use of valves. Fluorescent detection occurs using a diode laser. The system has been designed to have manufacturable, replaceable modules with simplicity for a non-technical end-user.

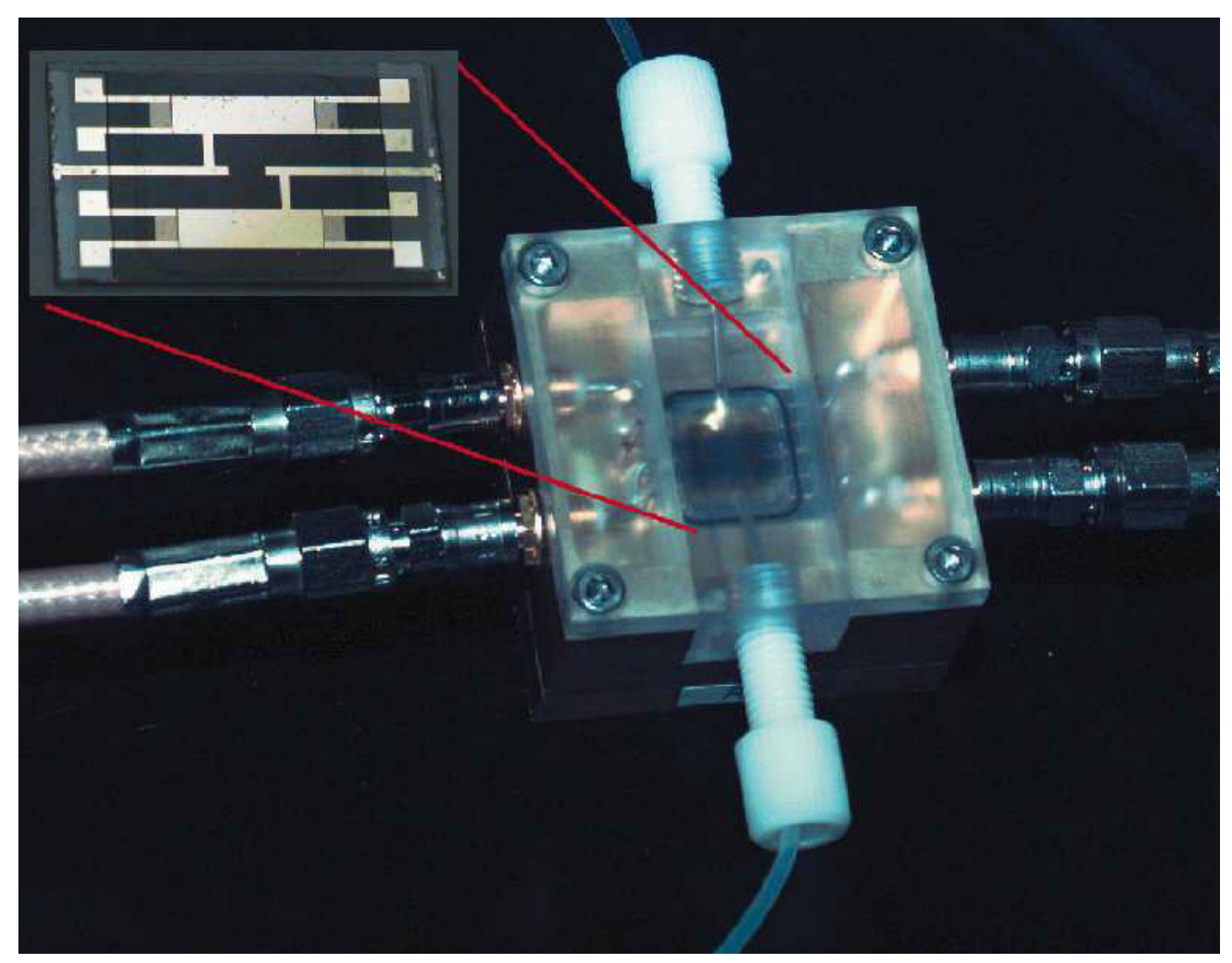

Figure 7. A miniaturized biosensor is shown consisting of a shear horizontal surface acoustic wave sensor coated with a molecular recognition layer. Highly specific coatings are used for biological warfare agent detection and medical diagnostics. 
Summary and specifications of sensor technologies

The following tables (Tab. 10 to Tab 13) summarize specifications for the sensor technologies described in the previous sections. In many cases, rigorous specifications are not available because of limited studies. In these cases, estimates are provided based on the judgment of the principal investigators.

Table 10. Summary of specifications for trace metal sensors.

\begin{tabular}{|c|c|c|c|c|c|c|c|c|}
\hline \multirow{2}{*}{$\begin{array}{c}\text { Sensor } \\
\text { Technology }\end{array}$} & \multicolumn{8}{|c|}{ Specifications } \\
\hline & Sensitivity & Selectivity & Stability & Speed & Size & Power & $\begin{array}{c}\text { User } \\
\text { Interface }\end{array}$ & Cost \\
\hline $\begin{array}{c}\text { A) } \\
\text { Nanoelectro } \\
\text { de Array }\end{array}$ & low ppb & $\begin{array}{l}\text { elemental } \\
\text { in non- } \\
\text { complex } \\
\text { mixtures }\end{array}$ & $\begin{array}{l}\text { long- } \\
\text { term }\end{array}$ & seconds & $\begin{array}{l}1 \text { square inch } \\
\text { dip probe }\end{array}$ & & $\begin{array}{l}\text { personal } \\
\text { computer }\end{array}$ & sensor: \\
\hline $\begin{array}{c}\text { B) } \\
\text { Laser- } \\
\text { Induced } \\
\text { Breakdown } \\
\text { Spectroscop } \\
\text { y }\end{array}$ & low ppb & elemental & $\begin{array}{l}\text { long- } \\
\text { term }\end{array}$ & $\begin{array}{c}\text { ms with } \\
\text { intensified-CCD, } \\
\text { minutes with } \\
\text { scanning } \\
\text { spectrometers } \\
\text { or signal } \\
\text { averaging }\end{array}$ & $\begin{array}{l}\text { fiber-optics; } \\
\text { lengths of } \\
100+\text { meters } \\
\text { possible }\end{array}$ & $\begin{array}{l}\text { mW per } \\
\text { pulse }\end{array}$ & $\begin{array}{l}\text { personal } \\
\text { computer }\end{array}$ & $\begin{array}{c}\text { system: } \\
\$ 50- \\
150 \mathrm{~K}\end{array}$ \\
\hline
\end{tabular}


$\widehat{\sim}$

\begin{tabular}{|c|c|c|c|c|c|c|c|}
\hline & $\begin{array}{l}\overrightarrow{0} \\
0 \\
0\end{array}$ & 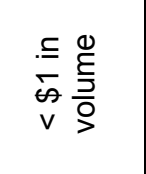 & 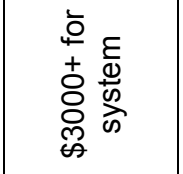 & 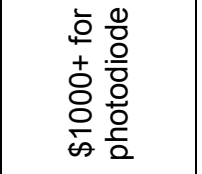 & 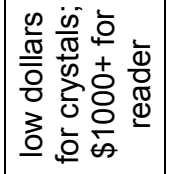 & & \\
\hline & 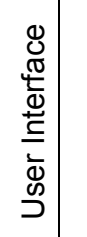 & 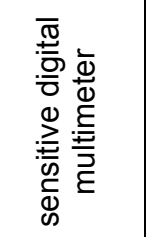 & 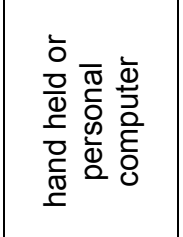 & 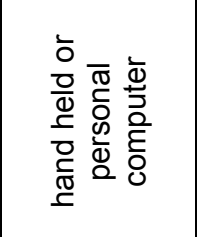 & 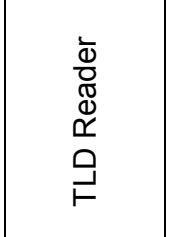 & 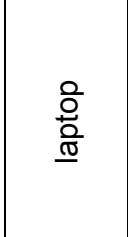 & $\begin{array}{l}\text { 용 } \\
\text { 임 }\end{array}$ \\
\hline & $\begin{array}{l}\bar{\Phi} \\
\hat{D}_{0} \\
0\end{array}$ & 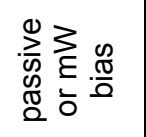 & 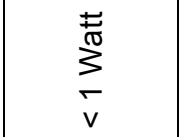 & 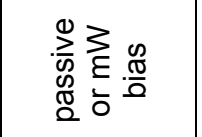 & 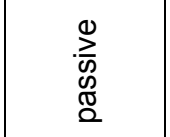 & $\begin{array}{l}0 \\
\stackrel{0}{0} \\
\stackrel{0}{r}\end{array}$ & $\begin{array}{l}0 \\
\stackrel{1}{0} \\
\stackrel{0}{r}\end{array}$ \\
\hline & $\stackrel{\mathscr{N}}{\infty}$ & 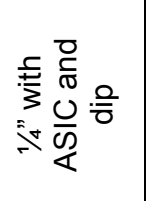 & 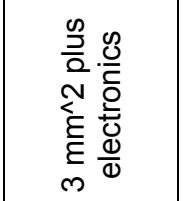 & 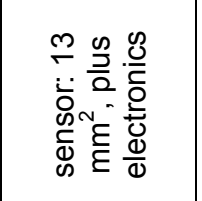 & 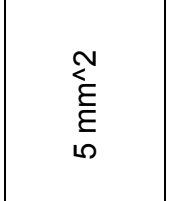 & 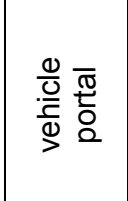 & 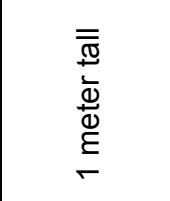 \\
\hline 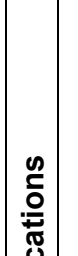 & 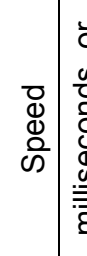 & 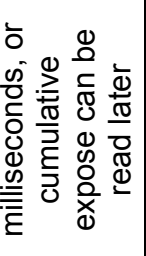 & 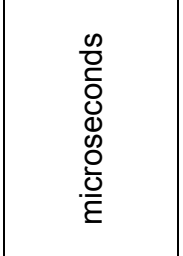 & $\begin{array}{l}\stackrel{\infty}{E} \\
\stackrel{\sim}{N}\end{array}$ & 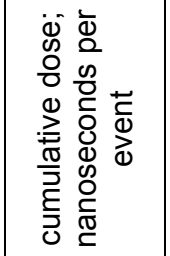 & $\begin{array}{l}\frac{\infty}{8} \\
0 \\
0 \\
\Phi \\
\infty\end{array}$ & $\begin{array}{l}\frac{\infty}{0} \\
\overline{0} \\
\stackrel{\vdots}{0} \\
\infty\end{array}$ \\
\hline के & 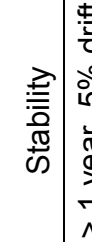 & 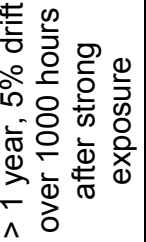 & 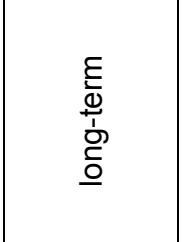 & 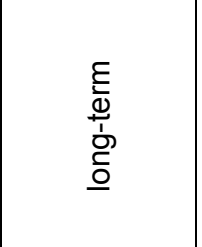 & 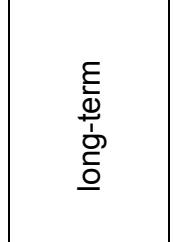 & $\begin{array}{l}\underline{E} \\
\underline{\Phi} \\
\underline{O} \\
\underline{\underline{\sigma}}\end{array}$ & $\begin{array}{l}\underline{\underline{E}} \\
\underline{\Phi} \\
\underline{\sigma} \\
\underline{\underline{\sigma}}\end{array}$ \\
\hline & 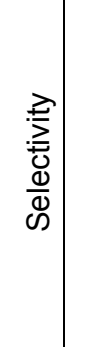 & 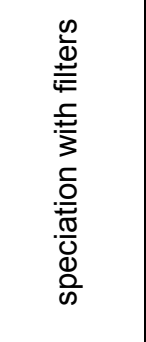 & 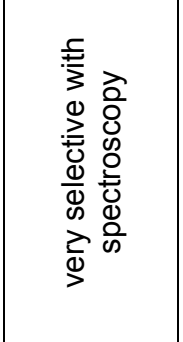 & 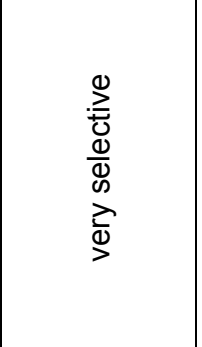 & 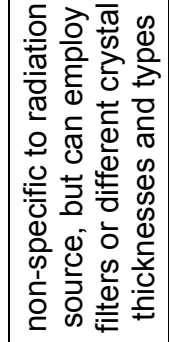 & 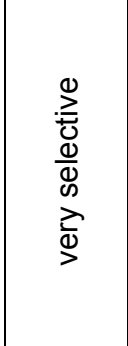 & 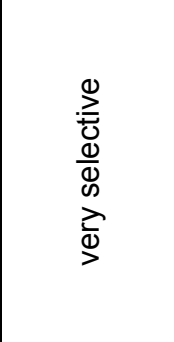 \\
\hline & 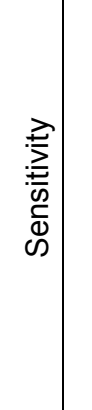 & 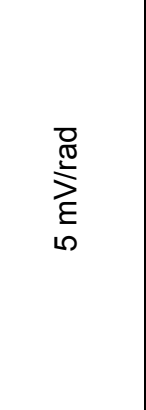 & 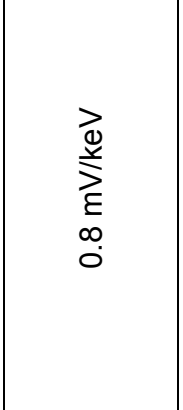 & 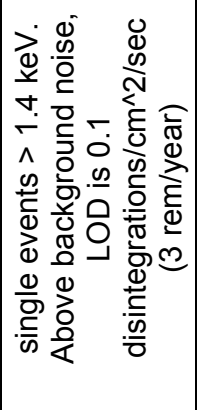 & 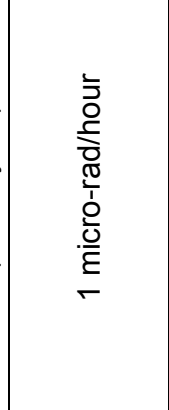 & 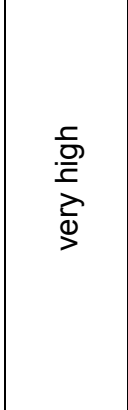 & 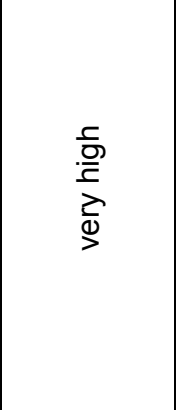 \\
\hline & 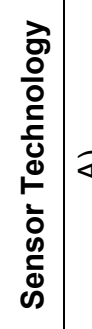 & 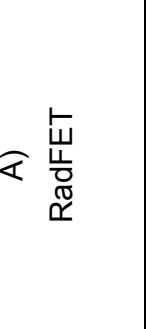 & 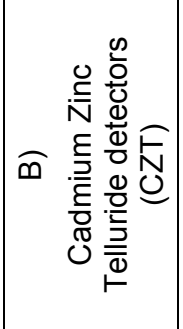 & 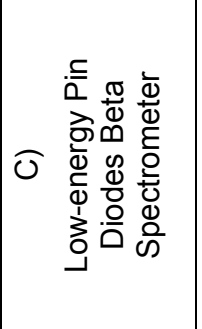 & 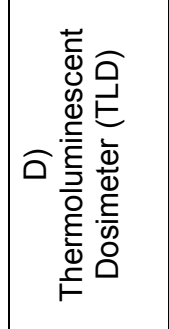 & 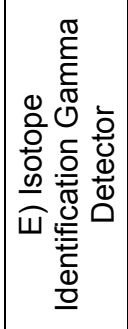 & 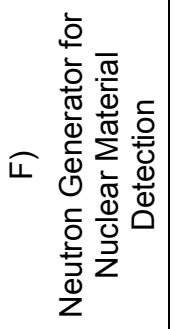 \\
\hline
\end{tabular}




\begin{tabular}{|c|c|c|c|c|c|c|c|c|c|c|c|}
\hline & 范 & 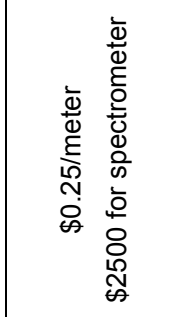 & $\begin{array}{l}\stackrel{8}{0} \\
\stackrel{b}{\leftrightarrow} \\
\text { v }\end{array}$ & 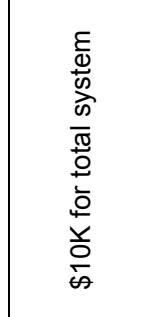 & $\begin{array}{l}\stackrel{8}{ } \\
\stackrel{b}{\leftrightarrow} \\
\vee\end{array}$ & 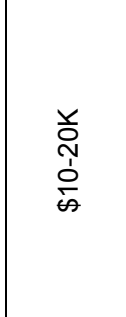 & $\frac{8}{\stackrel{8}{\dot{v}}}$ & 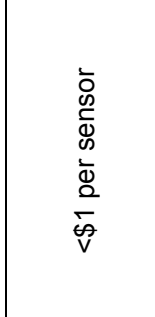 & 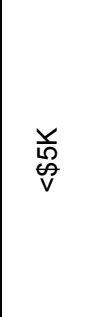 & $\begin{array}{l}\frac{y}{0} \\
\frac{0}{i s} \\
0 \\
\frac{\partial}{0} \\
\frac{0}{i s}\end{array}$ & 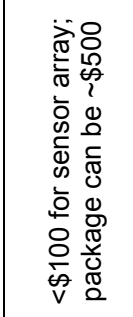 \\
\hline & 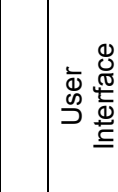 & 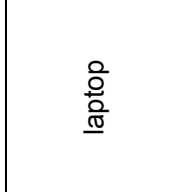 & 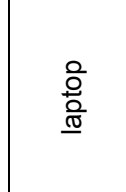 & $\begin{array}{l}\stackrel{\circ}{0} \\
\stackrel{\circ}{0} \\
\underline{\sigma}\end{array}$ & 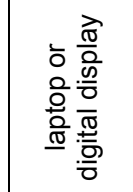 & 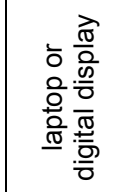 & 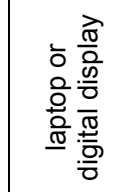 & $\begin{array}{l}\stackrel{\circ}{0} \\
\stackrel{0}{0} \\
\underline{\sigma}\end{array}$ & 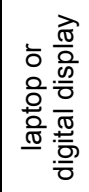 & $\begin{array}{l}\text { 윰 } \\
\text { 음 }\end{array}$ & 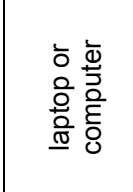 \\
\hline & 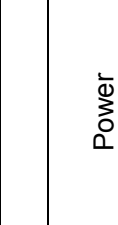 & 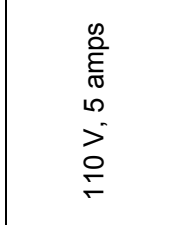 & 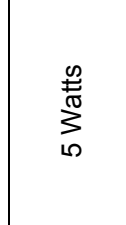 & 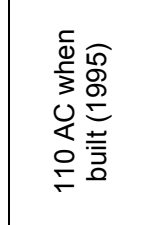 & \} $&{\begin{array}{l}\frac{E}{J^{0}} \\
\sum^{2} \\
v\end{array}} &{\text { \્ }} &{\text { 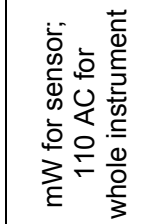 }} &{\text { 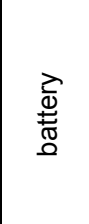 }} &{ } &{\text { 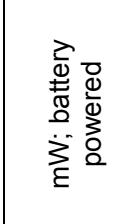 }} \\
{\hline} &{\frac{N}{\omega}} &{\text { 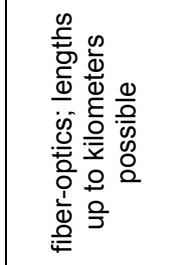 }} &{\begin{array}{l}0 \\
\frac{0}{0} \\
\frac{0}{0} \\
\stackrel{0}{0}\end{array}} &{\text { 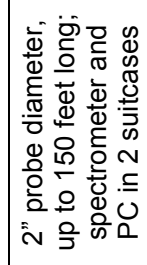 }} &{\text { 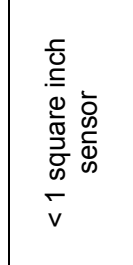 }} &{\begin{array}{l}\frac{0}{0} \\
\frac{\sigma}{\sigma} \\
\frac{\sigma}{\sigma} \\
\frac{\sigma}{\tau}\end{array}} &{\text { 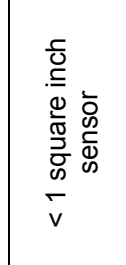 }} &{\text { 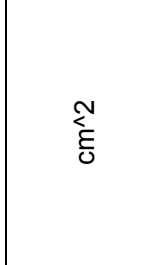 }} &{\begin{array}{l}\frac{0}{0} \\
\frac{\sigma}{\sigma} \\
\frac{\sigma}{\sigma} \\
\frac{\pi}{\Phi}\end{array}} &{\text { 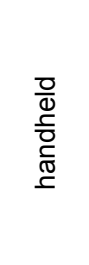 }} &{\text { 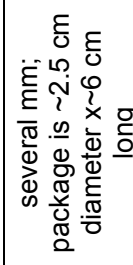 }} \\
{\hline \dot{0}} &{\text { 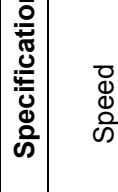 }} &{\text { 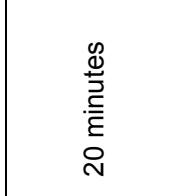 }} &{\text { 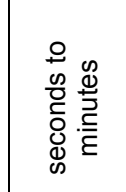 }} &{\text { 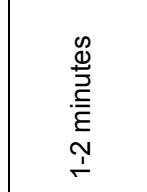 }} &{\text { 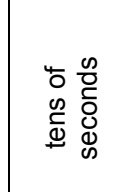 }} &{\text { 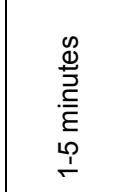 }} &{\text { 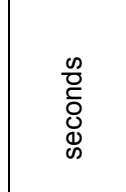 }} &{\text { 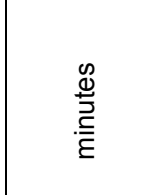 }} &{\text { 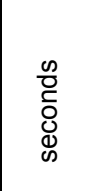 }} &{\text { 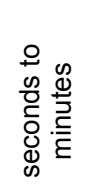 }} &{\text { 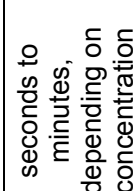 }} \\
{\hline \begin{array}{l}\int_{0}^{\infty} \\
0 \\
2 \\
0 \\
\vdots \\
0\end{array}} &{\text { 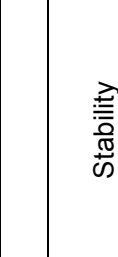 }} &{\text { 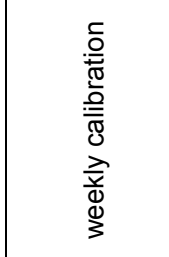 }} &{\text { 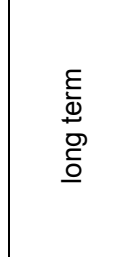 }} &{\text { 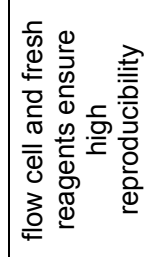 }} &{\text { 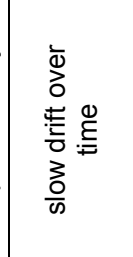 }} &{\text { 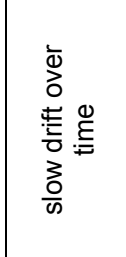 }} &{\text { 吕 }} &{\text { 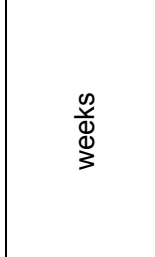 }} &{\text { 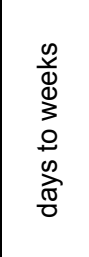 }} &{\begin{array}{l}\underline{\xi} \\
\underline{\Phi} \\
\underline{\sigma} \\
\underline{\sigma}\end{array}} &{\text { 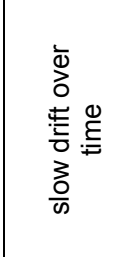 }} \\
{\hline \text { 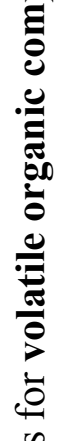 }} &{\begin{array}{l}\sum_{\bar{c}} \\
\frac{\Phi}{\Phi} \\
\infty\end{array}} &{\text { 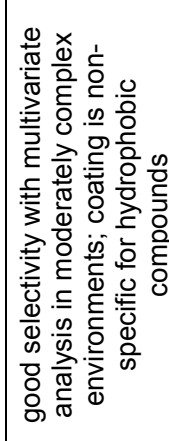 }} &{\text { 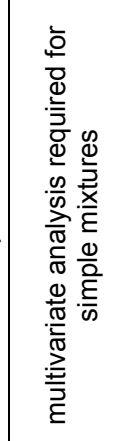 }} &{\text { 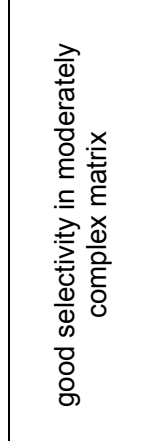 }} &{\text { 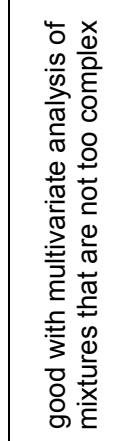 }} &{\text { 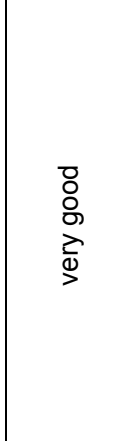 }} &{\text { 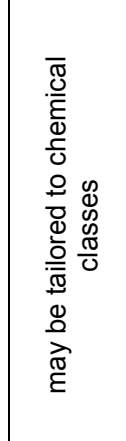 }} &{\text { 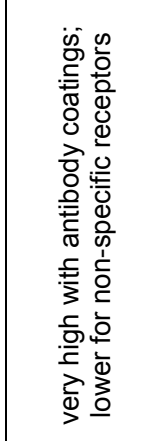 }} &{\text { 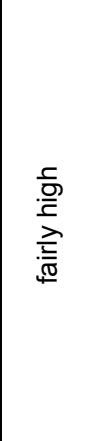 }} &{\text { 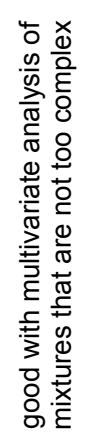 }} &{\text { 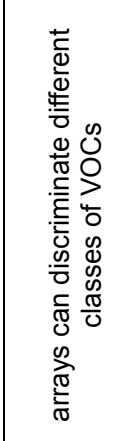 }} \\
{\hline \text { 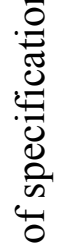 }} &{\text { 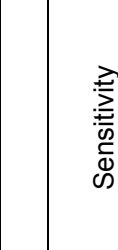 }} &{\text { 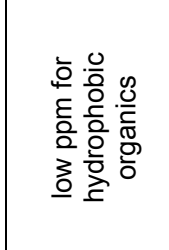 }} &{\begin{array}{l}\frac{0}{2} \\
\frac{0}{2} \\
\stackrel{2}{\varepsilon} \\
\frac{0}{2}\end{array}} &{\text { 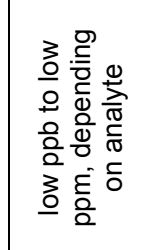 }} &{\begin{array}{l}\stackrel{0}{\circ} \\
\frac{0}{2} \\
\stackrel{2}{\varepsilon} \\
\frac{0}{2}\end{array}} &{\text { 음 }} &{\text { 음 }} &{\text { 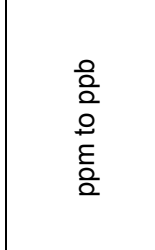 }} &{\text { 응 }} &{\begin{array}{l}\stackrel{0}{\circ} \\
\frac{0}{2} \\
\frac{0}{\varepsilon} \\
\frac{0}{2}\end{array}} &{\text { 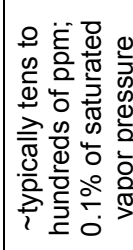 }} \\
{\hline \text { 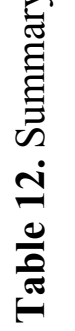 }} &{\text { 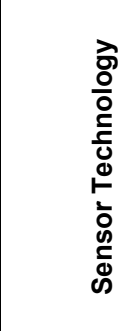 }} &{\text { 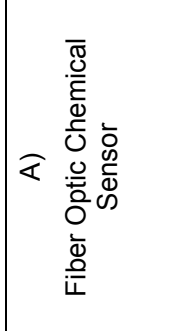 }} &{\text { 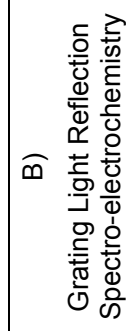 }} &{\text { 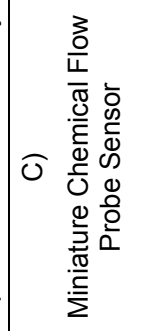 }} &{\text { 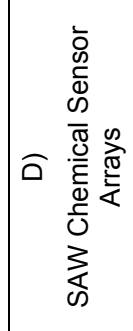 }} &{\text { 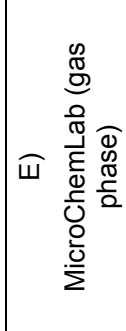 }} &{\text { 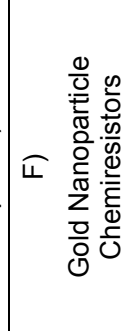 }} &{\text { 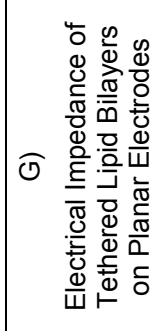 }} &{\text { 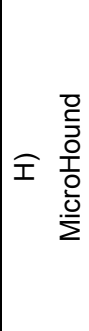 }} &{\text { 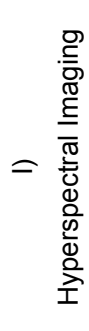 }} &{\text { 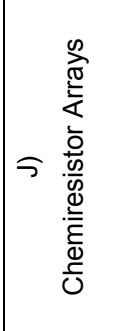 }} \\
$\hline
\end{tabular}




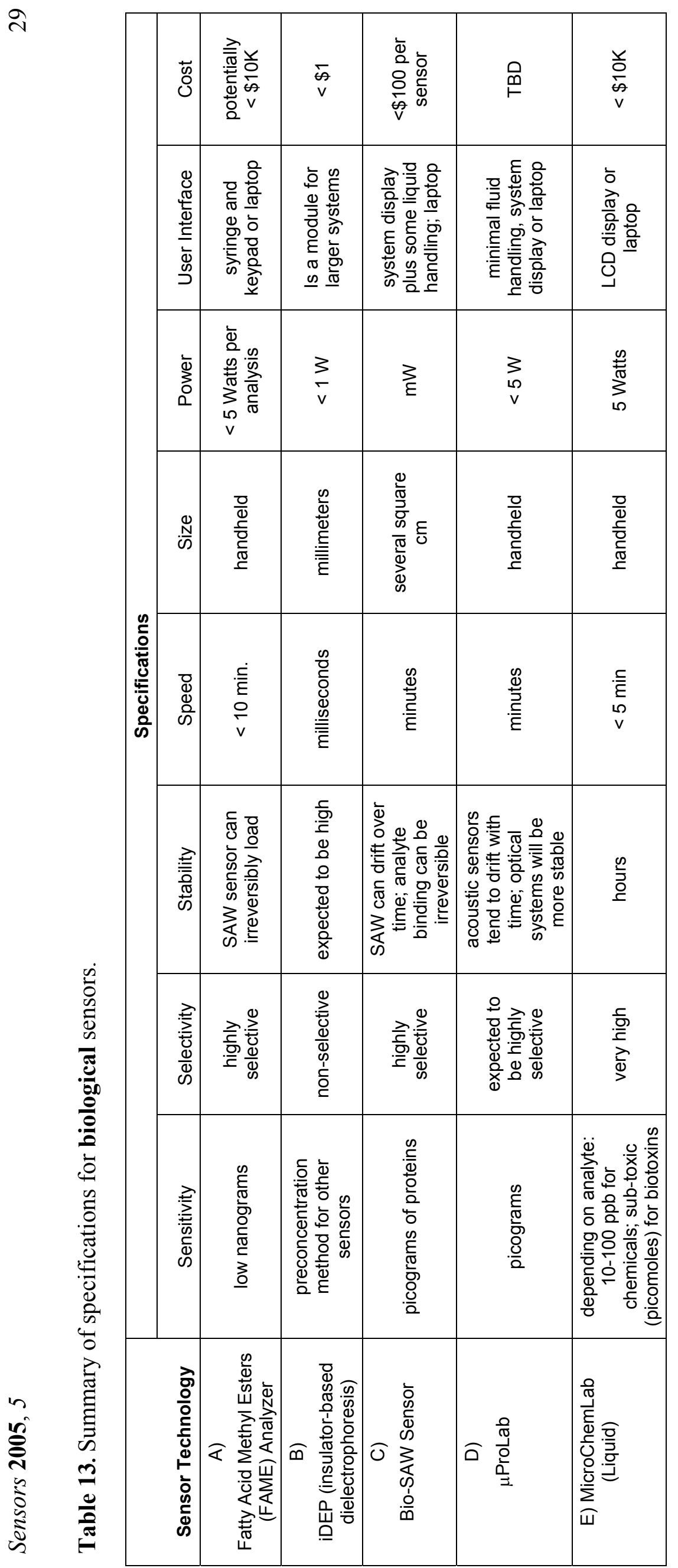




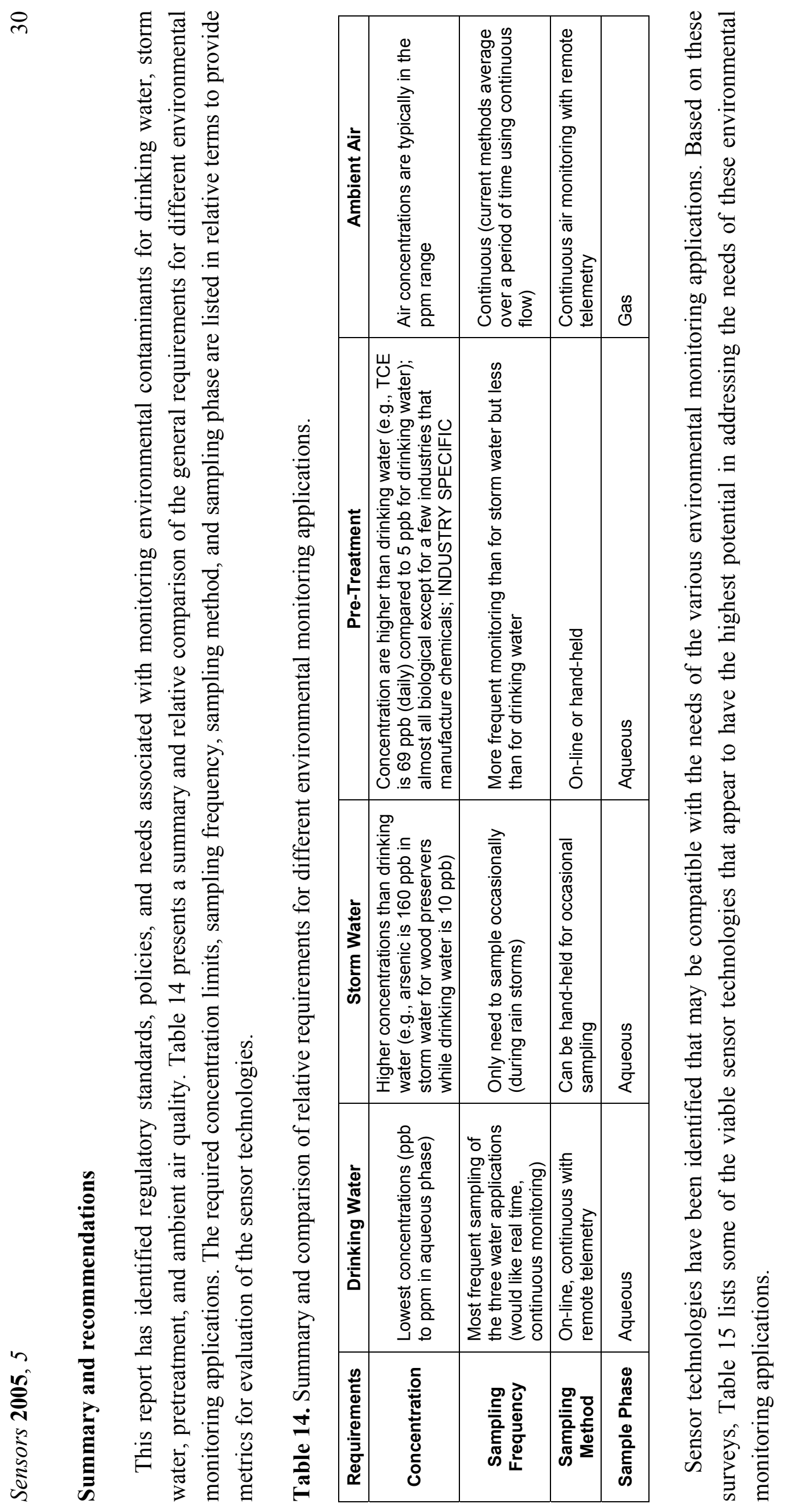




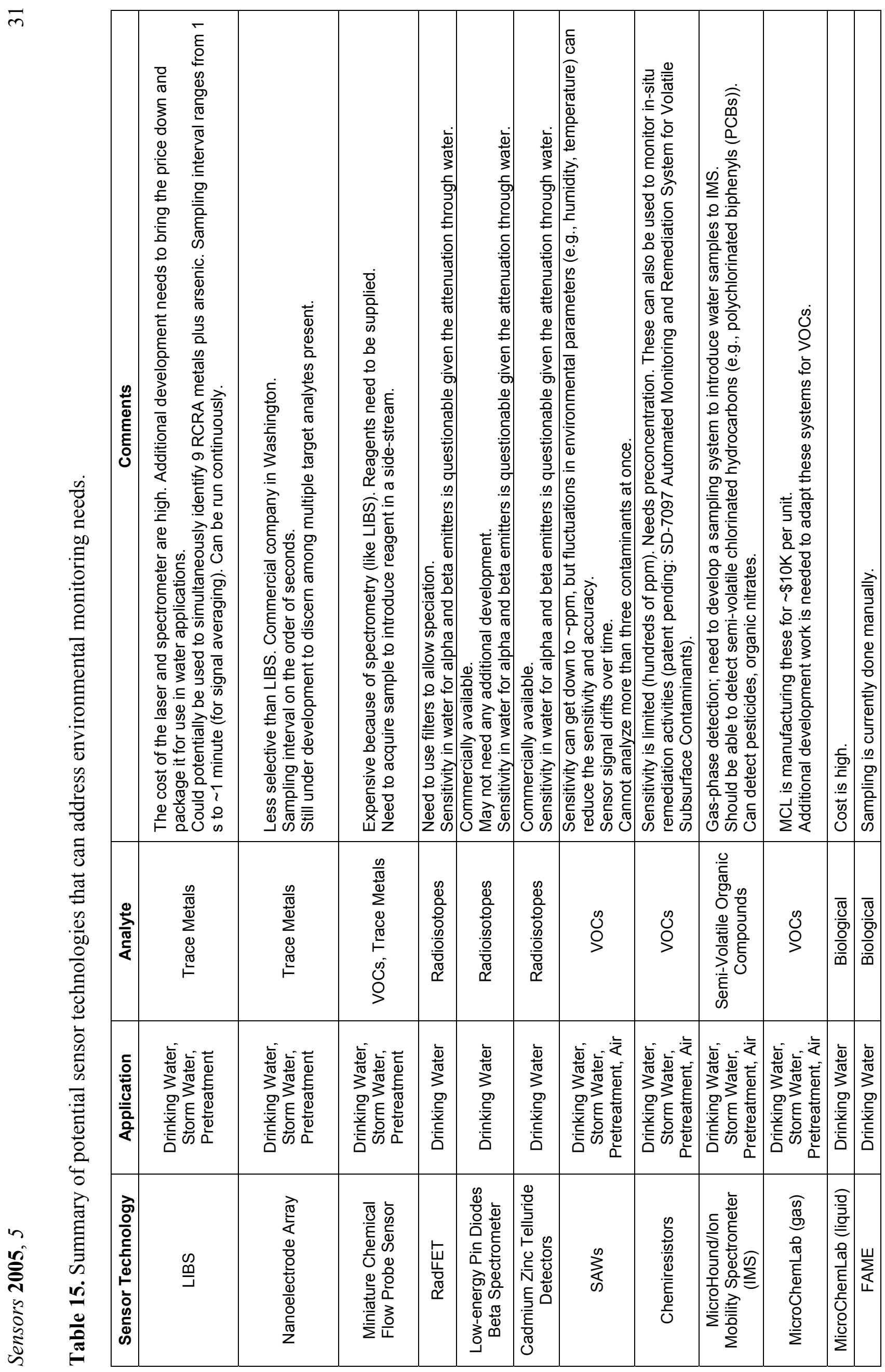




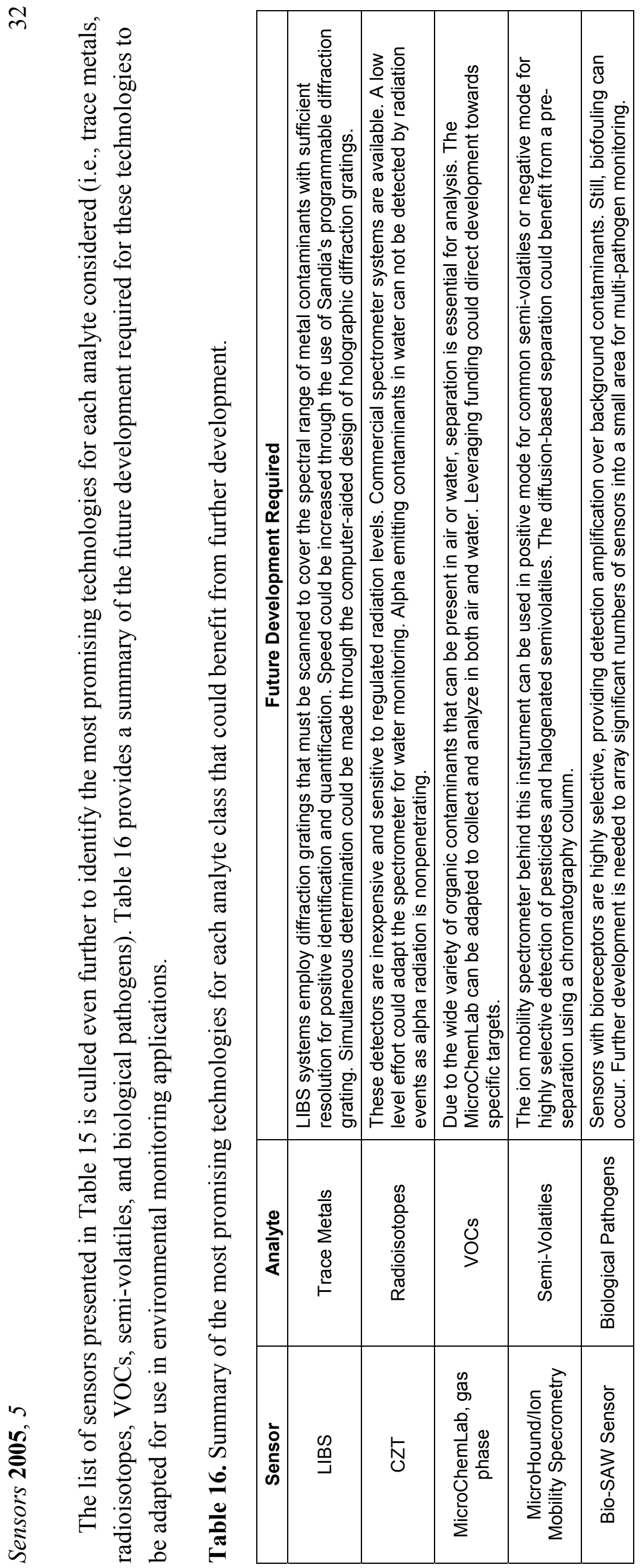


The advancement of the LIBS technology would be focused on developing a continuous LIBS sensor for water-monitoring applications. Ideally, the sensor would be able to simultaneously detect the nine RCRA metals plus arsenic at low ppb levels. The development of holographic diffraction gratings would increase the speed and efficiency of the LIBS ability to simultaneously detect these trace metals.

For the CZT sensors, a low-level effort is needed to adapt these sensors for water applications. A significant challenge will be to detect alpha-emitting contaminants since the radiation is attenuated rapidly. A continuous CZT sensor with spectrometry would need to be adapted for aqueous environments.

The MicroChemLab device requires additional development to detect VOCs in aqueous environments. Sampling, analysis, and parameter optimization (e.g., polymer selection) for target VOCs need to be pursued. With preconcentration, the sensitivity of these devices can be in the ppb range, but repeatability and drift are significant issues with MicroChemLab.

The ion mobility spectrometer implemented in the MicroHound shows promise for detecting semivolatile compounds such as pesticides and halogenated contaminants at low concentrations. Sampling methods would need to be developed to introduce aqueous samples to the IMS. Separation is based on the different "drift" times of the different ions through the IMS tube, but additional separation could be obtained by adding a chromatography column at the inlet. A great deal of research invested in the MicroHound project can be leveraged for applications in water monitoring and ambient-air monitoring (e.g., new materials and designs for the IMS drift tube).

The Bio-Saw sensor, and other continuous, real-time biological sensors, still require significant research and development before they can be applied to environmental monitoring applications. Bioassay test kits are available that can provide detection of biological agents, but these require manual operation and interfacing.

Of the sensors identified in Table 16, we believe that LIBS (for trace metals) and ion-mobility spectrometry (for semi-volatiles) show the most promise in terms of capabilities, adaptability, and potential impact. Both have the capability to detect concentrations at or below regulatory levels, and the ability to detect trace metals and semi-volatiles is needed in a number of environmental applications ranging from drinking-water to ambient-air monitoring.

A primary consideration that still remains to be addressed is the performance of these sensors in each of the field applications. Features such as sensitivity, stability, selectivity, speed, size, and cost need to be tested and evaluated under actual operating conditions. Harsh and fluctuating environmental conditions can degrade the performance of many of these sensors. Nevertheless, a market analysis presented in the beginning of this report indicates that a wide-ranging (and commercially viable) need can be filled by the successful development and application of these sensors to environmental monitoring applications. The sensor technologies identified in Table 15 and Table 16 appear to be the strongest candidates that can be further developed and adapted to address these needs. 


\section{Acknowledgments}

The authors thank Sue Collins, Steve Martin, Graham Yelton, and Jennifer Ellison for their insightful discussions and assistance with this report. Sandia is a multiprogram laboratory operated by Sandia Corporation, a Lockheed Martin Company for the United States Department of Energy's National Nuclear Security Administration under contract DE-AC04-94AL85000.

\section{References}

1. Looney, B.B; Falta, R.W., (Eds.) Vadose zone Science and Technology Solutions. Battelle Press, Columbus, OH, 2000, pp. 1540.

2. Wilson, LG.; Everett, L.G.; Cullen, S.J., (Eds.) Handbook of Vadose Zone Characterization \& Monitoring, CRC Press, Boca Raton, FL, 1995.

3. U.S. DOE. Assessment of the 2000 and 2001 Environmental Management Industry Times They Are A-Changin', Prepared for the U.S. Department of Energy Office of Environmental Management, Office of Science and Technology (EM-50). Prepared by YAHSGS Llc., Richland, Wa, August 2002.

4. Stetter, J. TES Workshop on Technology Needs as Part of a Conference on Analytical Chemistry and Applied Spectroscopy, Pittsburg, Pa, 2001.

5. U.S. Department of Energy. From Cleanup to Stewardship, a Companion Report to Accelerating Cleanup: Paths to closure and Background Information to Support the Scoping Process Required for the 1998 PEIS Settlement Study. U.S. Department of Energy, Office of Environmental Management, October 1999.

6. U.S. Department of Energy (DOE). Market Study to Determine Needs and Present Usage of Chemical Sensor Systems for Environmental Analytical Applications. Final Report. Submitted to: Characterization, Monitoring and Sensing Technology Crossscutting Program, Department of Energy, Ames Laboratory, Iowa State University, Ames, IA 50011-3020 Prepared by: The Unimar Group, Ltd. 325 Market St. , Alton, Il. 62002, May 1996.

7. Inspector General (IG) Report. Departmental Position on the Office of Inspector General Report IG-0461, "Groundwater Monitoring Activities at Department of Energy Facilities." To: Phillip L. Holbrook, Deputy Inspector General for Audit Services.

8. 65 Federal Register 64746. Final Reissuance of National Pollutant Discharge Elimination System (NPDES) Storm Water Multi-Sector General Permit for Industrial Activities; Notice, October 30, 2000.

9. 40 CFR Part 403. General Pretreatment Regulations for Existing and New Sources of Pollution. EPA, Washington, DC, 2000.

10. 40 Code of Federal Regulations (CFR). Part 414, Section 111, Organic Chemicals, Plastics, and Synthetic Fibers. EPA, Washington, DC, 2003. 
11. American Conference of Governmental Industrial Hygienists (ACGIH). Threshold Limit Values for Chemical Substances and Physical Agents and Biological Exposure Indices, ACGIH, Cincinnati, 2000.

12. Horton, R.J. "Sensor development: Micro-analytical solutions for water monitoring applications" SAND2003-2575P, Sandia National Laboratories, Albuquerque, NM, 2003.

13. Ashby, C.I.H.; Kelly, M.J.; Yelton, W.G.; Pfeifer, K.B.; Muron, D.J.; Einfeld, W.; Siegal, M.P. Functionalized nanoelectrode arrays for in situ identification and quantification of regulated chemicals in water. LDRD Annual Report, 2002, 364.

14. Hahn, D.W.; Hencken, K.R.; Johnsen, H.A. Performance testing of a laser-induced breakdown spectroscopy (LIBS) based continuous metal emissions monitor at a pyrolytic waste treatment facility. SAND97-8270, Sandia National Laboratories, Albuquerque, NM, 1997.

15. Matalucci, R.V.; Esparza-Baca, C.; Jimenez, R.D. Characterization, monitoring, and sensor technology catalogue. SAND95-3062, Sandia National Laboratories, Albuquerque, NM, 1995.

16. Blevins, L.G.; Shaddix, C.R.; Sickafoose, S.M.; Walsh, P. M. Laser-induced breakdown spectroscopy at high temperatures in industrial boilers and furnaces. SAND2003-8151J, Sandia National Laboratories, Albuquerque, NM, 2003.

17. Moreno, D.J.; Hughes, R.C.; Jenkins, M.W.; Drumm, C.R. A simple ionizing radiation spectrometer/dosimeter based on radiation sensing field effect transistors (RadFETs). SAND970255C, Sandia National Laboratories, Albuquerque, NM, 1997.

18. Murray, W.S.; Butterfield, K.B.; Baird, W. Automated radioisotope identification using fuzzy logic and portable CZT detectors. LA-UR-00-4791 (LANL), 2000.

19. Doyle, B.L.; Vizkelethy, G.; Walsh, D. Ion beam induced charge collection (IBICC) studies of cadmium zinc telluride (CZT) radiation detectors. SAND99-0917C, Sandia National Laboratories, Albuquerque, NM, 1999.

20. Wampler, W.R.; Doyle, B.L. Low-energy beta spectroscopy using pin diodes to monitor tritium surface contamination. Nuclear Instruments and Methods in Physics Research A, 1994, 349, 473.

21. Schwank, J.R.; et. al. "Common-source TLD and RADFET characterization of Co-60, Cs-137, and x-ray irradiation sources" SAND97-1440J, Sandia National Laboratories, Albuquerque, NM, 1997.

22. Carlson, G.A.; Lorence Jr., L.J.; Vehar, D.W. Particle size effect in CaF2: Mn-teflon TLD response at photon energies from 5 to $1250 \mathrm{KeV}$. SAND89-1788J, Sandia National Laboratories, Albuquerque, NM, 1989.

23. Garcia, N. Site hears latest news on four key R\&D projects. Sandia Lab News, Sandia National Laboratories, Albuquerque, NM, March 5, 2004, 56, 5, 3. 
24. Blair, D.S. Evaluation of an evanescent fiber optic chemical sensor for monitoring aqueous volatile organic compounds. SAND97-0782, Sandia National Laboratories, Albuquerque, NM, 1997.

25. Zaidi, S.; McNeil, J.R.; Kelly, M.J.; Sweatt, W.C.; Kemme, S.A.; Blair, D.S.; Brodsky, A.M., Smith, S.A. Grating light reflection spectroelectrochemistry for detection of trace amounts of aromatic hydrocarbons in water. SAND2000-1018, Sandia National Laboratories, Albuquerque, NM, 2000.

26. Ricco, A.; Xu, C.; Allred, R.; Crooks, R. SAW chemical sensor arrays using new thin-film materials. SAND94-0241C, Sandia National Laboratories, Albuquerque, NM, 1994.

27. Cernosek, R.W.; Frye, G.C.; Martin, S.J. Method and apparatus for phase and amplitude detection. U.S. Patent \# 5763283, 1994.

28. Sandia National Laboratoris, “ $\mu$ ChemLab" [online], December 9, http://wwwirn.sandia.gov/organization/mstc/organization/micro-analytical/chemlab.html, 2002.

29. Linker, K.L.; Brusseau, C.A.; Mitchell, M.A.; Adkins, D.R.; Pfeifer, K.B.; Rumpf, A.N.; Rohde, S.B. "Portable explosives detection system: MicroHound. SAND2003-2254C, Sandia National Laboratories, Albuquerque, NM, 2003.

30. Koehler, F.W.; Haaland, D.M. Quantitative determination of $2 \mathrm{D}$ hyperspectral image data. SAND99-2133A, Sandia National Laboratories, Albuquerque, NM, 1999.

31. Timlin, J.A.; Haaland, D.M.; Sinclair, M.B. Hyperspectral imaging and multivariate data analysis for biological and biomedical applications. SAND2003-3955A, Sandia National Laboratories, Albuquerque, NM, 2003.

32. Ho, C.K.; McGrath, L.K.; Davis, C.E.; Thomas, M.L.; Wright, J.L.; Kooser, A.S.; Hughes, R.C. Chemiresistor microsensors for in-situ monitoring of volatile organic compounds: final LDRD report. SAND2003-3410, Sandia National Laboratories, Albuquerque, NM, 2003.

33. Hughes, R.C.; Casalnuovo, S.A.; Wessendorf, K.O.; Savignon, D.J.; Hietala, S; Patel, S.V.; Heller, E.J. Integrated chemiresistor array for small sensor platforms, SPIE Proceedings Paper 4038-62, AeroSense 2000, Orlando, Florida, 2000, 519.

34. Ho, C.K.; Hughes R.C. In-Situ Chemiresistor sensor package for real-time detection of volatile organic compounds in soil and groundwater, Sensors, 2002, 2, 23.

35. Mowry, C.; Morgan, C.; Kottenstette, R.; Dulleck Jr., G.; Manginell, R.; Wally, K.; Baca, Q.; Theisen, L.; Chambers, W.; Trudell, D. LDRD annual report, Sandia National Laboratories, Albuquerque, NM, 2002, 65.

36. Simmons, B.A.; Cauley, T.H.; Charest, J.L. High-throughput insulative dielectrophoresis (iDEP) in bulk manufactured polypropylene. SAND2003-8512P, Sandia National Laboratories, Albuquerque, NM, 2003. 
37. Brozik, S.M.; Branch, D.W.; Osbourn, G.C.; Morgan, C.H.; Sasaki, D.Y. LDRD annual report. Sandia National Laboratories, Albuquerque, NM, 2002, 168.

38. Napolitano, L.M.; Potter, K.S.; Hasselbrink, E.; Brinker, C.J.; Wheeler, D.R.; Brozik, S.M.; Sasaki, D.Y.; Shepodd, T.J.; Singh, A.K.; Burns, A.R.; Casalnuovo, S.A.; Kemme, S.A.; Loy, D.A.; Bunker, B.C.; Thompson, A.P.; Potter, B.G.; Schoeniger, J.S. LDRD annual report. Sandia National Laboratories, Albuquerque, NM, 2002, 438.

39. Nolan, P. Sandia National Laboratories annual report 2003-2004. Sandia National Laboratories, Albuquerque, NM, 2004, 47.

(C) 2005 by MDPI (http://www.mdpi.org). Reproduction is permitted for non-commercial purposes. 